\title{
Św. Izydor z Sewilli, O rzekach
}

\author{
(Etymologiae, XIII, 21: De fluminibus, CPL 1186)
}

\section{Wstęp}

Izydor z Sewilli (ok. 560-636) zapisał się na kartach historii jako biskup, wybitny uczony, znawca łacińskiej literatury pogańskiej i chrześcijańskiej, wszechstronny pisarz, autor pism teologicznych, historycznych i dydaktycznych, twórca drobnych utworów poetyckich, wreszcie epistolograf'. Nieprzemijającą sławę przyniosło Izydorowi dzieło pt. Etymologiae sive Origines (napisane w latach 624-636) ${ }^{2}$, rodzaj encyklopedii w dwudziestu księgach, stanowiącej nieocenione kompendium ówczesnej wiedzy z zakresu sztuk wyzwolonych (artes liberales), nadto religii, prawa, historii, medycyny, zoologii, agronomii, geografii, etnologii czy architektury. Księga XIII tego interdyscyplinarnego traktatu, zatytułowana De mundo et partibus, została poświęcona zagadnieniom dotyczącym wszechświata i jego części. Biskup Sewilii podaje w niej ogólne informacje na temat m.in. wszechświata i jego budowy, nieba i jego części (np. pięciu kręgów nieba, atmosfery), zjawisk meteorologicznych (np. tęczy, chmur, wiatrów, grzmotów, błyskawic), wody i różnych jej rodzajów (np. mórz, oceanów, zatok morskich, cieśnin, jezior, stawów, rzek). Należy w tym miejscu odnotować, że zasadnicze kwestie związane z kosmogonią i historią naturalną poruszył Izydor już wcześniej, bo w roku 613, w innym dziele noszącym tytuł De natura rerum ${ }^{3}$.

Spośród bogactwa treści zawartych w XIII księdze Etymologii naszą szczególną uwagę zwrócił obszerny rozdział dwudziesty pierwszy ( $D e$ fluminibus), traktujący o najważniejszych rzekach starożytnego świata.

1 Por. T. Krynicka, Izydor z Sewilli, Kraków 2007.

2 Por. A.V. Canale, Quadro storico, w: Isidoro di Siviglia, Etimologie o Origini, t. 1, red. A.V. Canale, Novara 2014, 26.

3 Por. Św. Izydor z Sewilii, O naturze rzeczy (rozdz. IX-XXVIII). De natura rerum, CPL 1188, tt. P. Skowroński, VoxP 36 (2016) t. 65, 835-857. 
Bardzo ogólny wykład na ten sam temat zawarł Sewilczyk w trzeciej i ostatecznej edycji wspomnianego pisma De natura rerum, w geograficzno-etymologicznym apendyksie De nominibus maris et fluminibus (rozdz. XLVIII) $)^{4}$.

Hydrografią starożytnego świata zajmowali się zarówno wielcy poeci, jak i wybitni pisarze o szerokich zainteresowaniach. Już Hezjod, najsłynniejszy poeta beocki, zamieścił w Teogonii krótki katalog znanych mu rzek ${ }^{5}$. Prozaiczne traktaty o rzekach świata antycznego napisali m.in. Kallimach z Cyreny, Warron, a Pliniusz Starszy poświęcił im sporo uwagi w swojej encyklopedii zatytułowanej Naturalis historia. Bliżej nieznany pisarz rzymski Wibiusz Sekwester stworzył alfabetyczny katalog rzek, źródeł i jezior występujących w rzymskiej literaturze pięknej (Vibii Sequestris de fluminibus, fontibus, lacubus, nemoribus, paludibus, montibus, gentibus per literras libellus) ${ }^{6}$. W literaturze greckiej zachowało się analo-

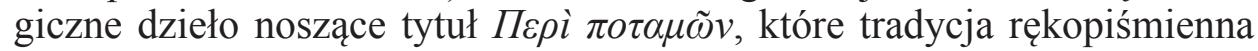
przypisała słynnemu pisarzowi greckiemu Plutarchowi z Cheronei ${ }^{7}$. Nie były to jedyne próby opisania antycznych hydronimów, gdyż autor traktatu

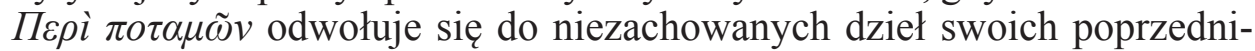
ków, między innymi Agatoklesa z Miletu, Agatona z Samos, Archelaosa, Arystonima, Arystotelesa, Chrysermosa, Ktezjasza z Knidos, Demaratosa, Demostratosa z Apamei, Leona z Bizancjum, Nikanora z Samos, Sostratosa z Nysy, Timagorasa, Timoteosa. Widzimy zatem, że zainteresowanie rzekami było do tego stopnia powszechne, że biskup Sewilli nie omieszkał podążyć drogą długiej, bo wywodzącej się od Hezjoda, tradycji.

W ustępie dotyczącym rzek antycznej ekumeny Izydor z Sewilli omówił w pierwszej kolejności terminy hydrograficzne, starając się - zgodnie z tytułem dzieła - wyjaśnić ich etymologię i pochodzenie. Następna partia, poświęcona biblijnym nazwom rzek, zaczyna się od wyliczenia czterech rajskich cieków. Autor podążył w swym opisie za Księgą Rodzaju (2,1014), która przynosi następujące wiadomości:

4 Por. J. Fontaine, Introduction, w: Isidore de Séville, Traité de la nature, suivi de l'Épître en vers du roi Sisebut à Isidore, red. J. Fontaine, Bibliothèque de l'École des hautes études hispaniques 28, Bordeaux 1960, 82. Zob. Krynicka, Izydor z Sewilli, s. 57.

5 Por. Hezjod, Theogonia, 337-345, t1. J. Łanowski, w: Hezjod, Narodziny bogów (Theogonia), Prace i dni, Tarcza, Warszawa 1999, 41.

6 Por. Vibius Sequester, De fluminibus, fontibus, lacubus, nemoribus, paludibus, montibus, gentibus per literras libellus, red. R. Gelsomino, Lipsiae 1967.

7 Por. Plutarco, Fiumi e monti, introduzione, testo critico, traduzione e commento, red. E. Calderón - A. De Lazzer - E. Pellizer, Napoli 2003. Zob. także: Plutarco, Vidas de los diez oradores. Sobre la astucia de los animales. Sobre los ríos, oprac. I. Rodríguez Moreno, Madrid 2005. 
Z Edenu zaś wypływała rzeka, aby nawadniać ów ogród, i stamtąd się rozdzielała, dając początek czterem rzekom. Nazwa pierwszej - Piszon; jest to ta, która okrąża cały kraj Chawila, gdzie się znajduje złoto. A złoto owej krainy jest wyborne; jest tam także wonna żywica i onyks. Nazwa drugiej rzeki - Gichon; okrąża ona cały kraj Kusz. Nazwa rzeki trzeciej - Chiddekel; płynie ona na wschód od Aszszuru. Rzeka czwarta to Perat"8.

W przekonaniu Izydora cztery rzeki noszące nazwy Piszon, Gichon, Chiddekel oraz Perat wypływają z Edenu i następnie toczą swoje wody po Ziemi. Autor Etymologii kojarzy je z czterema potężnymi i sławnymi rzekami: Gangesem, Nilem, Tygrysem i Eufratem. Następnie Sewilczyk wylicza inne rzeki płynące w Azji, włącznie z Tanaisem (Donem), który jego zdaniem oddziela Azję od Europy. Nadchodzi teraz kolej na największe lub najbardziej znane cieki europejskie wyliczone w kolejności geograficznej ze wschodu na zachód, co sprawia, że w końcowej partii omówione zostają główne rzeki Hiszpanii (noszące miano Iberus, Mineus, Durius, Tagus, Baetis), które prawdopodobnie znał (lub mógł znać) Izydor z autopsji. Ważnym elementem opisu hydrografii świata antycznego jest objaśnienie nazw wodnych bazujące na ówczesnej wiedzy geograficznej dobrze wykształconego mieszkańca zachodniej Europy.

Biskup Sewilli w opisie rzek przywołuje nominatim Hieronima, Lukana, Marcjalisa, Owidiusza, Pakuwiusza, Sallustiusza oraz Wergiliusza (dwukrotnie), cytując w większości przypadków fragmenty ich dzieł. Nie ulega jednak wątpliwości, że do opracowania passusu poświęconego starożytnej hydronimii wykorzystał on też inne źródła zarówno chrześcijańskie (m.in. dzieła św. Ambrożego, św. Hieronima, Laktancjusza), jak i pogańskie (m.in. gramatyczno-etymologiczne dzieło O języku łacińskim Warrona, komentarze Serwiusza Maurusa, wybitnego rzymskiego gramatyka, scholiasty pieśni Wergiliusza, Historię naturalna Pliniusza Starszego, Zbiór rzeczy godnych pamięci Solinusa).

Rozdział De fluminibus z uwagi na swój kompendialny i interdyscyplinarny charakter stanowi ponadczasową, ciekawą lekturę, obfitującą w wiele cennych uwag z zakresu językoznawstwa (etymologii), geografii, historii i mitologii. Za sprawą Izydorowego opracowania antyczny czytelnik, żądny uporządkowanej wiedzy, otrzymuje w przystępnej formie podstawowe informacje o najważniejszych rzekach, z którymi zetknęła się grecko-rzymska cywilizacja. Prezentowany poniżej przekład daje ogólne wy-

8 Cytat za: Pismo Święte Starego i Nowego Testamentu w przekładzie z języków oryginalnych, opracował Zespół Biblistów Polskich z inicjatywy Benedyktynów Tynieckich, Poznań 2000. 
obrażenie o stanie wiedzy wielu pokoleń Europejczyków korzystających z encyklopedycznego dzieła biskupa Sewilli.

\section{Bibliografia}

\subsection{Wydania tekstu}

Migne J.P., Parisiis 1878, PL 82, 489-494.

Lindsay W.M., Isidori Hispalensis episcopi Etymologiarum sive Originum libri XX, t. 1-2, Oxonii 1911.

\subsection{Przekłady nowożytne}

\section{Angielski:}

Barney S.A. - Lewis W.J. - Beach J.A. - Berghof O., The Etymologies of Isidore of Seville, Cambridge 2006.

\section{Wloski:}

Valastro Canale A., Isidoro di Siviglia, Etimologie o Origini, t. 1-2, Novara 2014.

\subsection{Opracowania}

Агеева Р.А., Происхождение имен рек и озер, Москва 1985.

Albaigès J.M., Enciclopedia de los topónimos españoles, Barcelona 1998.

Beekes R., Etymological Dictionary of Greek, Leiden - Boston 2010.

Bijak U., Nazwy wodne dorzecza Wisty. Potamonimy odapelatywne, Kraków 2013.

Carnoy A., Dictionnaire étymologique de la mythologie gréco-romaine, Louvain 1957.

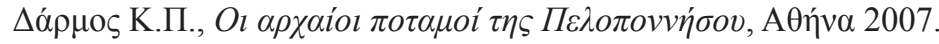

Dizionario di toponomastica. Storia e significato dei nomi geografici italiani, red. G. Gasca Queirazza et alii, Torino 2005.

Faure Sabater R., Diccionario de nombres geográficos y étnicos del mundo, Madrid 2004. Félice R. de, Les noms de nos rivières. Leur origine. Leur signification, Paris 1906.

Ferrari A., Dizionario del luoghi del mito. Geografia reale e immaginaria del mondo classico, Milano 2011.

García Alonso J.L., La Península Ibérica en la Geografía de Claudio Ptolomeo, Vitoria 2003. 
Georgiev V., Die altgriechischen Flussnamen, Sofia 1958.

Kaczyńska E., Glosy obcojęzyczne w dziele Pseudo-Plutarcha De fluviis, „Meander” 68 (2013) 56-71.

Krynicka T., Świat roślin w XVII księdze Etymologii Izydora z Sewilli, Lublin 2007.

Krynicka T., Izydor z Sewilli, Kraków 2007.

Lexikon der indogermanischen Verben, red. H. Rix, Wiesbaden 2001.

Marcato C., Nomi di persona, nomi di luogo. Introduzione all'onomastica italiana, Bologna 2009.

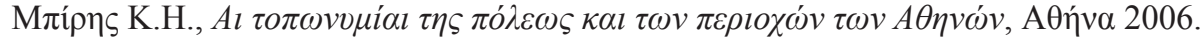

Pellegrini G.B., Toponomastica italiana. 10000 nomi di città, paesi, frazioni, regioni, contrade, fiumi, monti spiegati nella loro origine e storia, Milano 2008.

Pokorny J., Indogermanisches etymologisches Wörterbuch, Bern - München 1959.

Pomponiusza Meli Chorografia czyli Opis kręu ziemi, tł. M. Golias, Piotrków Trybunalski 2011.

Renzo A., Nomi d'Italia. Origine e significato dei nomi geografici e di tutti i comuni, Novara 2009.

Rosół R., Frühe semitische Lehnwörter im Griechischen, Frankfurt am Main 2013.

Rozwadowski J., Studia nad nazwami wód słowiańskich, Kraków 1948.

Sobotka P., Etymologizowanie $i$ etymologia. Od semantyki ontologicznej do etymologii hermeneutycznej, Warszawa 2015.

Staszewski J., Mały stownik. Pochodzenie i znaczenie nazw geograficznych, Warszawa 1968.

Tischler J., Kleinasiatische Hydronymie. Semantische und morphologische Analyse der griechischen Gewässernamen, Wiesbaden 1977.

Tronina A. - Walewski P., Biblijne nazwy osobowe i topograficzne. Stownik etymologiczny, Częstochowa 2009.

Vaan M. de, Etymological Dictionary of Latin and the Other Italic Languages, Leiden Boston 2008.

Witczak K.T., The Latin Origin of the River Name Tiberis, „Latomus: Revue d'études latines" 73 (2014) z. 1, 3-10.

\section{Przekład 9}

1. Rzeka (fluvius) to nieprzerwany wypływ wody; została tak nazwana, ponieważ ciągle płynie (a fluendo perpetim) ${ }^{10}$. Ściśle zaś mówiąc, wyrazem

9 Przekładu dokonano na podstawie dwujęzycznego wydania: A. Valastro Canale, Isidoro di Siviglia, Etimologie o Origini, t. 2, Novara 2014, 150-161.

10 Podana etymologia jest poprawna. Zob. rdzeń pie. *bhleuH- ('płynąć'; por. Lexikon der indogermanischen Verben, red. H. Rix, Wiesbaden 2001, 90), skąd łac. fluō 
flumen określa się samą wodę, a wyrazem fluvius - jej bieg ${ }^{11}$. Słowo flumen jest wcześniejsze niż fluvius, jako że woda poprzedza swój bieg. Można wyróżnić dwa rodzaje wody płynącej: wodę rwącą (torrens) oraz wodę bieżącą (flumen vivum). O tej ostatniej mówi Wergiliusz: Donec me flumine vivo abluero ('Dopóki świeżą wodą się nie obmyję') ${ }^{12}$.

2. Potok (torrens) to woda płynąca $z$ impetem. Został tak nazwany, ponieważ przybiera podczas deszczu, z powodu zaś suszy ,jest przypiekany" (torrescit), to znaczy wysycha ${ }^{13}$. O nim mówi Pakuwiusz: Flammeo vapore torrens torret ('Potok praży gorąca para') ${ }^{14}$. Jego nazwę Grecy utworzyli od zimy (ab hieme $)^{15}$, my natomiast - od lata (ab aestate $)^{16}$. Tamci nazwali go od pory roku, w której się tworzy, my - od pory roku, w której wysycha.

3. Wyrazem amnis określa się rzekę płynącą w gaju, wśród zieleni; zawdzięcza nazwę pięknemu otoczeniu (ex amoenitate) ${ }^{17}$.

('płynąć, ociekać, wypływać, rozlewać się'), gr. att. $\varphi \lambda \varepsilon \dot{\varepsilon} \omega$ ('wytryskać, obfitować'), $\varphi \lambda v ́ \omega$ ('przelewać się, wytryskać, wrzeć, burzyć się'), stpol. bluję, blwać ('wymiotować').

11 Definicję apelatywów fluvius i flumen wprowadził jako pierwszy M. Terencjusz Warron (Ling. V, 27): fluvius, quod fluit, item flumen [...]; flumen quod fluit continue.

12 Por. Vergilius, Aeneis, II, 719 (tł. własne). Zob. Publiusz Wergiliusz Maro, Eneida, tł. T. Karyłowski, Wrocław - Warszawa - Kraków - Gdańsk 1980, 65: „póki żywe tonie nie obmyją mnie".

13 Por. Servius, Commentarii in Vergilii Aeneidos libros, II, 305: „Torrens fluvius qui aestate siccatur, unde et nomen accepit".

14 Trzy pierwsze wyrazy tego cytatu, pochodzące z tragedii Pakuwiusza pt. Antiopa, stanowią część dłuższego passusu (frg. 12-14 Ribb.): „[...] sol si perpetuo siet, / flammeo vapore torrens terrrae fetum exusserit. / Omnia nocti ni interveniat sol pruina obriguerint” ("Jeśliby słońce nieprzerwanie świeciło, gorącą parą potok spaliłby płody ziemi. Wszystko zdrętwiałoby od szronu, jeśliby słońce nie stanęło nocy na przeszkodzie').

15 Chodzi o grecki termin hydrograficzny $\chi \varepsilon \mu \mu \alpha \rho \rho \rho o \varsigma$ (att. $\chi \varepsilon \mu \mu \alpha \rho \rho \rho \varsigma^{\prime} \mathrm{m}$.) ('potok wezbrany w porze zimowej, rwący potok, rzeka, strumień'), por. ap. $\chi \varepsilon i ́ \mu \omega v$ m. ('zima') i czas. ṕć ('płynąć'). Zob. Servius, Commentarii in Vergilii Aeneidos libros, II, 305: „Cui [sc. torrenti] Graeci per contrarium dedere vocabulum; nam $\chi \varepsilon 1 \mu$ á $\rho \rho o o v$ dixerunt a tempore quo crescit".

16 Por. Izydorową etymologię łac. aestas (Etym. V, 35, 4): ,aestas dicitur ab aestu, id est a calore" ('Przyjmuje się, że wyraz aestas pochodzi od aestus, tj. od ciepła'). Rzymianom znana była poprawna etymologia wyrazu za sprawą Warrona (Ling. VI, 9), który dopuszczał zestawienie łacińskiego apelatywu z greckim czasownikiem $\alpha$ î $\theta \omega$ ('zapalać, rozpalać, płonąć'; < pie. *h $h_{2}$ eidh- 'ts.'). Por. też łac. aedes ('dom, świątynia'; pierwotnie 'ognisko domowe, ogień sakralny').

17 Łaciński apelatyw amnis wywodzi się z pie. *h, $e b-n$ - ('rzeka'). Por. stirl. $a b, a u b$, także abann f. ('rzeka'), wal. afon f. ('rzeka'; < pracelt. *abonā); het. hapaš c. ('rzeka'), palajskie hapnaš 'ts.' (< praanat. *h $\left.{ }_{2} e b-\right)$. Zob. M. de Vaan, Etymological Dictionary of Latin and the Other Italic Languages, Leiden - Boston 2008, 39. W starożytności popular- 
4. Decursus ('spad') jest to właściwie koniec biegu wody albo jakiejkolwiek innej rzeczy. Kanały (rivi) zostały tak nazwane, ponieważ wykorzystywane są do odprowadzania wody (deriventur) ${ }^{18}$ do irygacji (ad inrigandum), tj. do zaopatrywania pól w wodę (ad inducendum aquas in agris). Słowo inrigare ('nawadniać') znaczy bowiem to samo co inducere ('doprowadzać [wodę]').

5. Wir (gurges) jest to, ściśle mówiąc, głęboki punkt w rzece. Studnia (puteus) to wydrążone miejsce, z którego czerpie się wodę; nazwana tak od picia (a potatione) $)^{19}$. Źródło (fons) jako początek wypływającej wody [podziemnej] zwie się tak z tego powodu, że wylewa wody (fundans aquas) ${ }^{20}$.

6. Niektóre rzeki otrzymały nazwy z powodu swych charakterystycznych właściwości. Warte odnotowania są zwłaszcza te, które często pojawiają się w dziełach historycznych.

7. Geon ${ }^{21}$ to rzeka wypływająca z Edenu (Paradisus) i opasująca całą Etiopię ${ }^{22}$, która zawdzięcza nazwę temu, że wskutek podnoszenia stanu

ne było objaśnienie wyrazu amnis za pomocą czasownika ambīre ('obchodzić, opływać, otaczać') bądź jego synonimów. Zob. Varro, Ling. V, 28; Fest, De verborum significatione 16 (Müller).

18 Rzeczownik rīvus m. ('mały strumień, potok, kanał'), poprawnie zestawiony z czasownikiem derīvare ('odprowadzać wodę, kierować w inną stronę, odwracać bieg płynącej wody)', pozostaje w związku z skt. rílyate ('płynąć gwałtownie [powodując wiry], wirować'), skt. rītí- f. ('strumień, ruch'), gr. ỏ - 'falować, wrzeć, kipieć, wirować, kręcić się’). Zob. J. Pokorny, Indogermanisches etymologisches Wörterbuch, Bern - München 1959, 330-331; Rix, Lexikon, s. 305.

19 Objaśnienie Izydora niewątpliwie należy do kategorii etymologii fantastycznych. Trzeba jednak przyznać, że źródłosłów apelatywu puteus nie został jak dotąd wskazany. Wyraz najczęściej jest zestawiany z łacińskim czasownikiem putare ('oczyszczać, przycinać'), por. też miasto w pobliżu Neapolu zwane Puteoli m. pl. (dosł. 'studzienki’). Niektórzy językoznawcy uważają łaciński wyraz za zapożyczenie. Zob. de Vaan, Etymological Dictionary, s. 502.

20 Termin hydrograficzny fons wywodzi się z pie. *dhonh dhani ('biec, płynąć'; < ie. *dhénh - ), awest. dānu- ('rzeka'), oset. don ('woda, rzeka'; < prair. *dānu-). Zob. Pokorny, Indogermanisches, s. 249; Rix, Lexikon, s. 144; de Vaan, Etymological Dictionary, s. 231. Wyraz fons nie ma nic wspólnego z czas. fundere ('lać, wylewać'; < ie. * $\hat{g} h u-n-d$-), który zresztą jest sabinizmem (łacińska forma brzmiałaby *hundere).

21 Pod nazwą Geon kryje się zapewne biblijny Gichon (hebr. גיחון), jedna z czterech rajskich rzek (Rdz 2,13). Por. hebr. gichon ('kipiel'). Zob. A. Tronina - P. Walewski, Biblijne nazwy osobowe i topograficzne. Słownik etymologiczny, Częstochowa 2009, 126.

22 W starożytności pod nazwą Etiopii rozumiano ogólnie obszar położony na południu Ziemi, którego mieszkańcy wystawieni byli na silne działanie promieni słonecz-

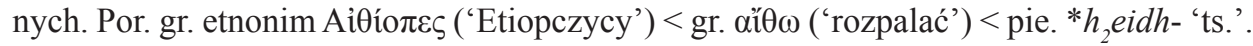


swojej wody nawadnia ziemię Egiptu; grecki bowiem wyraz $\gamma \tilde{\eta}$ oznacza po łacinie 'ziemię'. Tę rzekę Egipcjanie nazywają Nilem ${ }^{23}$ z powodu naniesionego przez nią mułu, który użyźnia glebę; stąd rzeka nosi nazwę Nil, to znaczy véa ìús ('nowy muł') 24 , albowiem Nil dawniej po łacinie był nazywany Melo ${ }^{25}$. Rzeka bierze początek w Jeziorze Nilowym ${ }^{26}$, skąd kieruje się na południe, a następnie ku Egiptowi, gdzie smagana podmuchami Akwilonu, wiejącego z północy, stawia gwałtowny opór, a wzbierając, zalewa Egipt ${ }^{27}$.

8. Rzeka Ganges ${ }^{28}$, którą Pismo Święte nazywa Piszon (Phison), wypływa z Edenu (Paradisus) i zmierza w kierunku Indii. [Ganges] nosi nazwę

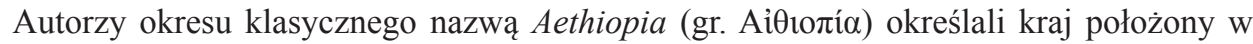
górnym biegu Nilu (poniżej Egiptu), rozciągający się pomiędzy pierwszą kataraktą (dzis. Aswān w Egipcie) a czwartą (dzis. Meroe w północnym Sudanie), zwany też Nubią. Egipcjanie początkowo tylko Górną Nubię, z czasem cały kraj, nazywali Kuszem (egip. $K w s ̌)$ wzmiankowanym w kontekście rajskiej rzeki w Rdz 2,13: „Nazwa drugiej rzeki Gichon; okrąża ona cały kraj - Kusz".

23 Nil (gr. Neĩ $о$ os, łac. Nīlus, dzis. Nahr an-Nīl) - najdłuższa rzeka świata (o długości 6695 km), formująca się z dwóch rzek źródłowych Nilu Niebieskiego i Nilu Białego (zw. w górnym biegu Kagerą), wypływających odpowiednio z Jeziora Tana (w Etiopii) i Jeziora Wiktorii (w Ugandzie). Obie odnogi łączą się w okolicach Chartumu w Sudanie. Nil uchodzi do Morza Śródziemnego rozległą deltą (por. Catul. XI, 7-8: „,septemgeminus [...] Nilus" - 'Nil mający siedem ujść'). Por. Hieronymus, De situ et nominibus locorum Hebraicorum liber, 215, PL 23, 945: „Geon, fluvius, qui apud Aegyptios Nilus vocatur, in paradiso oriens, et universam Aethiopiam circumiens".

24 Por. Servius, Commentarii in Vergilii Aeneidos libros, IX, 30: „Nilus dictus est quasi véav ì v́v, hoc est novum limum trahens".

25 Por. Sextus Pompeius Festus, De verborum significatione, 124 (Müller): „Melo nomine alio Nilus vocatur"; Servius, Commentarii in Vergilii Aeneidos libros, IV, 246: „Nilus [sc. Latine dicitur] Melo”.

26 Por. Solinus, Collectanea rerum memorabilium, XXXII, 3: „[sc. Nilus] lacum efficit, quem Nilidem dicunt”. Pod łacińską nazwą Nīlis lacus (< gr. *Neı $\lambda \grave{i} \varsigma \lambda i ́ \mu v \eta)$ kryje się zapewne Jezioro Wiktorii (ok. $69 \mathrm{~km}^{2}$ powierzchni), największy zbiornik wodny w Afryce.

27 Por. Ambrosius, Hexaemeron, II, 3, 12, PL 14, 163: „Nilus effuso Aegyptum stagnans flumine" ('Nil występuje z brzegów, zalewając Egipt'). Zob. Św. Ambroży, Hexaemeron, tł. W. Szołdrski, Warszawa 1969, 69.

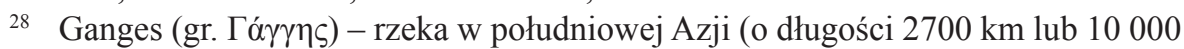

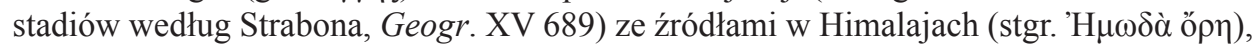
przepływa przez Indie i Bangladesz. Tworząc wraz z rzeką Brahmaputrą największą na świecie deltę (,pięcioramienną” według Ptolemeusza, Geogr. VII, 1, 18), uchodzi do

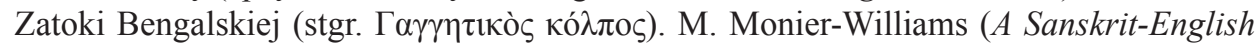
Dictionary, Delhi 1999, 341) objaśnia nazwę Gangesu jako „swift-goer” ('prędko idący, tj. płynący’). Nazwa rzeki z czasem uległa apelatywizacji i przybrała znaczenie hy- 
Piszon, co znaczy 'zbiorowisko' (caterva) ${ }^{29}$, ponieważ przyjmuje dziesięć dużych dopływów, które tworzą tę jedną rzekę. Ganges zawdzięcza nazwę Gangarowi ${ }^{30}$, królowi Indii. Opowiadają, że wzbiera jak Nil ${ }^{31}$ i rozlewa się na ziemie Orientu.

9. Tygrys (Tigris) ${ }^{32}$ to rzeka w Mezopotamii, która wypływa z Edenu (Paradisus) ${ }^{33}$ i zmierza w kierunku asyryjskich granic; po zakreśleniu wielu zakoli wpada do Morza Martwego. [Rzeka] została tak nazwana z powodu jej wartkiego nurtu jakby na podobieństwo do tygrysa (tigris), dzikiego zwierzęcia, które potrafi w biegu osiągnąć ogromną prędkośćc ${ }^{34}$.

drograficzne ('rzeka'). Por. syng. gan̆gā f. ('rzeka'), asam. gāning f. ('Ganges; rzeka'), beng. gāà ('rzeka, zwł. Ganges)', hi. mar-gãg m. ('suchorzecze, suche koryto rzeki'). Zob. R.L. Turner, A Comparative Dictionary of the Indo-Aryan Languages, London 1966, 211. Najbardziej znanym polskim przykładem terminu hydrograficznego, powstałego w wyniku apelatywizacji nazwy rzecznej, jest wyraz „dunaj” ('głęboka woda, głębina, rzeka, strumień, woda'; < n. rz. Dunaj). Zob. U. Bijak, Nazwy wodne dorzecza Wisły. Potamonimy odapelatywne, Kraków 2013, 61.

29 Nazwa rajskiej rzeki Piszon (hebr. פיוֹיוֹ), kojarzonej z Gangesem, oznacza '(rzekę) tryskającą'. Zob. Tronina - Walewski, Biblijne nazwy, s. 218 (Rdz 2,11; Syr 24,25). Por. Hieronymus, De situ et nominibus locorum Hebraicorum liber, 211, PL 23, 943: „Fison, quod interpretatur, caterva: fluvius quem nostri (Graeci) Gangen vocant, de paradiso exiens, et pergens ad Indiae regiones, post quas erumpit in pelagus".

30 Gangarydami (łac. Gangaridae) nazywano ludy mieszkające po obu stronach Gangesu (Serv. Sch. in Georg. III, 27).

31 Por. Solinus, Collectanea rerum memorabilium, LII, 6: „Gangen quidam [...] Nili modo exultare contendunt".

32 Tygrys (gr. Tí $\gamma \rho\rceil \varsigma \|$ Tírpı, dzis. Nahr Dijlah) - rzeka o długości $1950 \mathrm{~km}$ biorąca początek w Taurusie Armeńskim (górach wznoszących się we wschodniej Turcji), ok. 25 km na pd. wsch. od miasta Elâzı ̆̆. Tygrys stanowi granicę pomiędzy Turcją i Syrią na odcinku 44 km. Płynie przez Irak Niziną Mezopotamską, w środkowym biegu mija Bagdad. Łączy się z Eufratem, z którym, tworząc rzekę Szatt al-Arab (o długości ok. 150 km), wpada do Zatoki Perskiej.

33 Z pewnością chodzi tu o Chidekkel (hebr. חידקל), rajską rzekę identyfikowaną z Tygrysem. Zob. Tronina - Walewski, Biblijne nazwy, s. 268 (Rdz 2,14; Tb 6,1-2.; Jdt 1,6; Syr 24,25; Dn 10,4).

34 Izydor z Sewilli w innym miejscu swoich Etymologii (XII, 2, 7) podaje explicite, że hydronim Tigris wywodzi się od wyrazu tigris ('tygrys'), który w języku perskim i medyjskim oznacza 'strzałę': „tigris vocata propter volucrem fugam; ita enim nominant Persae et Medi sagittam. [...] ex cuius nomine flumen Tigris appellatur, quod is rapidissimus sit omnium fluviorum" ("tygrys został tak nazwany z powodu szybkiego biegu; tym bowiem wyrazem Persowie i Medowie określają strzałę. Od tego wyrazu nazwano rzekę Tygrys, ponieważ jest ona najszybsza ze wszystkich rzek'). Taki wywód nazwy zwierzęcia i rzeki podał już wcześniej Warron z Reate (I wiek p.n.e.), który jednak apelatyw tigris wywodził z języka ormiańskiego (Ling. V, 100): „tigris [...] vocabulum e lingua Armenia, 
10. Eufrat ${ }^{35}$ jest rzeką $\mathrm{w}$ Mezopotamii, wypływającą $\mathrm{z}$ Edenu (Paradisus $^{36}$, bogatą $\mathrm{w}$ kamienie szlachetne ${ }^{37}$. Przepływa przez Babilonię $e^{38}$. [Eufrat] wziął swoją nazwę od plonów lub od urodzaju, ponieważ Ephrata

nam ibi et sagitta et quod vehementissimum flumen dicitur Tigris". Uznanie hydronimu Tigris, a co za tym idzie apelatywu tigris ('strzała'), za perski zawdzięczamy żyjącemu w I wieku p.n.e. rzymskiemu historykowi Kurcjuszowi Rufusowi (Hist. Alex. Magn. IV, 9, 16: „Itaque, a celeritate qua defluit, Tigri nomen est inditum, quia Persica lingua Tigrim sagittam appellant”). Por. aw. tigri- m. ('strzała'), aw. tiłra- adi. ('spiczasty, ostry'), stpers. tigra- adi. ('spiczasty, ostry'), skt. tigmá- 'ts.' oraz gr. czas. $\sigma \tau i$ $\zeta \omega$ ('tatuować, piętnować'). Zob. Ch. Bartholomae, Altiranisches Wörterbuch, Strassburg 1904, 651. Popularne w starożytności objaśnienie rzeki Tygrys uważa się powszechnie za błędne. Zob. R. Beekes, Etymological Dictionary of Greek, Leiden - Boston 2010, 1481-1482. Należy podkreślić, że pierwotna nazwa rzeki była pochodzenia sumeryjskiego. Została ona zarejestrowana $\mathrm{w}$ napisach klinowych w formie Idigna (dosł. 'biegnąca rzeka', tj. szybko płynąca - running river), skąd akad. Idiqlat, Diqlat, syr. Deqlat, arab. Diğla, orm. Dktat', osm.-tur. Dicle. Zob. W.F. Albright, The Evidence of Language, w: The Cambridge Ancient History, t. 1, cz. 1, red. J. Boardman et alii, Cambridge 1976, 148. Rozpowszechniona w świecie

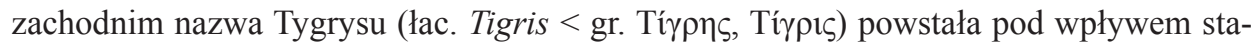
roperskiej postaci Tigrā, stanowiącej adaptację akadyjskiej nazwy rzecznej (pierwotnie sumeryjskiej).

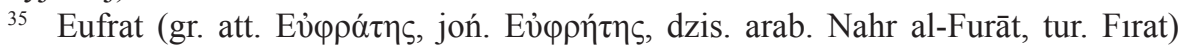
- wielka rzeka zach. Azji (o długości $2760 \mathrm{~km}$ ), tworzy się we wschodniej Turcji (na Wyżynie Armeńskiej) z dwóch rzek źródłowych Kara Su (dosł. 'czarna woda' = ant. Axius w Armenii), zw. też Eufratem Zachodnim, oraz Murat Su (= ant. Pactolus lub Arsanias w Armenii), zw. też Eufratem Wschodnim. Oba cieki łączą się w regionie Elaziğg, niedaleko

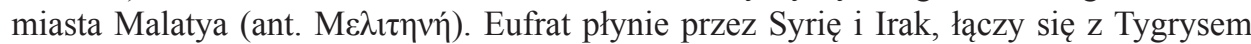
w pobliżu miasteczka al-Qurnah, formując rzekę Szatt al-Arab, która wpada do Zatoki Perskiej. W starożytności sądzono, że rzeka Eufrat uchodziła do morza osobnym korytem (np. Herodot, Hist. I 180).

36 Z Eufratem identyfikowano Perat (hebr. פרת), jedną z czterech rzek biblijnego Edenu. Zob. Tronina - Walewski, Biblijne nazwy, s. 115 (Rdz 2,14; Syr 24,26). Por. Hieronymus, De situ et nominibus locorum Hebraicorum liber, 202, PL 23, 939: „Euphrates, fluvius Mesopotamiae, in paradiso oriens”.

37 Z traktatu De fluviis (XX, 2) Pseudo-Plutarcha dowiadujemy się, że w wodach

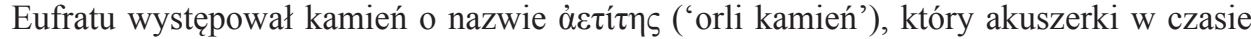
ciężkich porodów kładły na brzuchu rodzącej kobiety dla uśmierzenia bólów. Szlachetne kamienie, podobne do sardonyksu (odmiany chalcedonu o naprzemianległych białych i brunatnoszarych warstwach), występowały z kolei na pobliskiej górze Drimyllon. Miały one zdobić królewskie diademy. Por. Ps.-Plutarchus, De fluviis, XX, 4.

38 Babilonia - potężne państwo przeżywające swój rozkwit w czasach panowania Hammurabiego (1792-1750 p.n.e.), zajmowało rozległą równinę Mezopotamii, rozciągającą się pomiędzy dolnymi biegami rzek Eufratu i Tygrysu. Babilonia zawdzięczała nazwę leżącemu nad Eufratem miastu Babilon. 
po hebrajsku oznacza żyzność (fertilitas) ${ }^{39}$. W niektórych miejscach Eufrat nawadnia Mezopotamię tak samo jak Nil Aleksandrię. Sallustiusz, pisarz godny zaufania, twierdzi ${ }^{40}$, że Tygrys i Eufrat biorą początek $z$ tego samego źródła w Armenii, dalej zaś płyną oddzielnie w różnych kierunkach, tworząc między sobą przestrzeń o ogromnej powierzchni. Ten właśnie obszar, który jest przez nie opływany, nosi nazwę Mezopotamii ${ }^{41}$. Na tej podstawie Hieronim ${ }^{42}$ wydał osąd, iż powinno się przyjąć inną interpretację odnośnie do rzek wypływających z Edenu.

11. Indus ${ }^{43}$ to rzeka na Wschodzie, która wpada do Morza Czerwonego (Mare Rubrum) $)^{44}$.

39 Częste wylewy rzeki użyźniały w starożytności tereny leżące w jej dolinie, stąd też u św. Hieronima (De nom. Hebr. 48, PL 23, 854) rzeka Eufrat określana jest przydawką frugifer ('żyzny, płodny'). Należy jednak zaznaczyć, że pierwotna nazwa rzeki była sumeryjskiego pochodzenia i brzmiała Buranuna, skąd akad. Purattu, het. Puranti, elam. Upratu, stpers. Ufrātu, hebr. Parāt, arab. Furāt, tur. Fırat. Zob. J. Tischler, Kleinasiatische Hydronymie. Semantische und morphologische Analyse der griechischen Gewässernamen, Wiesbaden 1977, 53. Rzeka otrzymała nazwę od czynności „płynięcia”. Zob. J. Staszewski, Mały stownik. Pochodzenie i znaczenie nazw geograficznych, Warszawa 1968, 133.

40 Por. Sallustius, Historiae (fr.), IV, 77.

41 Mezopotamia - starożytna kraina leżąca w dorzeczu rzek Eufratu i Tygrysu, była kolebką cywilizacji sumeryjskiej i babilońsko-asyryjskiej (ob. Irak). Jej grecka nazwa

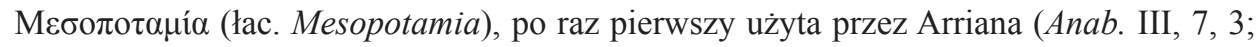
VII, 7, 3), oznacza 'międzyrzecze'. Por. gr. $\mu \varepsilon ́ \sigma o \varsigma$ adi. ('środkowy, położony pomiędzy')

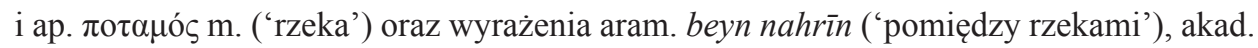
māt birìt nārim 'ts.', określające rejon pomiędzy zakolem Eufratu a jego dwoma dopływami (dzis. Balīh oraz Habur).

42 Por. Hieronymus, De situ et nominibus locorum Hebraicorum liber, 202, PL 23, 939.

43 Indus - najważniejsza rzeka pd.-wsch. Azji (o długości 3180 km), wypływająca z podnóży góry Kajlas w Transhimalajach. Płynie przez zachodni Tybet (Chiny), Indie i Pakistan, uchodzi rozległą deltą do Morza Arabskiego na pd. wsch. od miasta Karaczi. W starożytności główna rzeka Persji. Nazwa perska Hindu-, skąd na skutek psylozy gr. 'Ivó́ $\varsigma$ (> łac. Indus), wywodzi się od skt. ap. síndhu- m. / f. ('rzeka'). Por. Sindus u Plin. Nat. hist. VI, 71. Temu hydronimowi zawdzięczają swą nazwę Indie, kraj w pd. Azji położony nad Oceanem Indyjskim.

44 Terminem Mare Rubrum (gr. 'E $\rho \theta \rho \alpha \grave{~} \theta \alpha ́ \lambda \alpha \sigma \sigma \alpha$ ) w starożytności nazywano nie tylko dzisiejsze Morze Czerwone, ale też zachodnie rejony Oceanu Indyjskiego. Izydor (Etym. XIII, 17, 4) podaje, że Morze Czerwone dzieli się na dwie zatoki: Perską i Arabską (,Hoc mare [sc. Rubrum] in duos sinus scinditur. Ex his, qui ab oriente est, Persicus appellatur, quia ora illius Persae inhabitant. Alter vero Arabicus dicitur, quod sit circa Arabiam"). 
12. Hystaspes ${ }^{45}$ był pradawnym królem Medów ${ }^{46}$, od którego przejęła miano rzeka na Wschodzie, nosząca teraz nazwę Hydaspes ${ }^{47}$. O tej rzece pisze $\operatorname{Lukan}^{48}[\ldots]$. Choć jest to perska rzeka, niemniej jednak pojawiają się głosy, że płynie ona jeszcze bardziej na wschód [poza Persję].

45 Już u Laktancjusza (III/IV wiek n.e.) znajdujemy wywód hydronimu Hydaspes od imienia króla Hystaspesa (Div. inst. VII, 15, 19): „Hystaspes [...] Medorum rex [...], a quo amnis nomen accepit, qui nunc Hydaspes dicitur”. Chodzi tu zapewne o Hystaspesa (stpers. Vištāspa '[mający] gotowe konie'), legendarnego króla z rodu Kejanidów, ukazanego w Aweście, zwolennika i protektora Zaratusztry, proroka i twórcy religii zw. zaratusztrianizmem. Od epoki hellenistycznej pod imieniem Hystaspesa krążył zbiór proroctw pt. Oracula, z którego korzystali m.in. Laktancjusz, Justyn Męczennik, Klemens Aleksandryjski. Historyk rzymski z IV wieku n.e. Ammianus Marcellinus (Res gest. XXIII, 6, 32) zidentyfikował Hystaspesa, patrona Zaratusztry, z innym Hystaspesem (VI wiek p.n.e.) z perskiej dynastii Achemenidów, satrapą Partii, ojcem Dariusza I Wielkiego, władcy Persji. Ten drugi Hystaspes nigdy nie sprawował władzy królewskiej.

46 Pod etnonimem „Medowie” (gr. Mñoor, łac. Mēdī) należy rozumieć starożytny lud irański spokrewniony z Persami. Media, kraina geograficzna położona na pd. wsch. od Armenii, została przyłączona do Persji ok. 550 r. p.n.e. przez króla perskiego Cyrusa II Wielkiego (panującego w latach 559-529 p.n.e.). Potomkami Medów są współcześni Kurdowie.

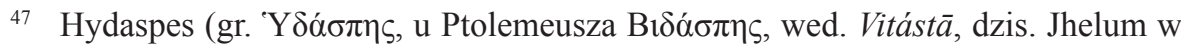
Pakistanie) to rzeka (o długości $725 \mathrm{~km}$ ) mająca źródło w masywie Pir Panjal na połu-

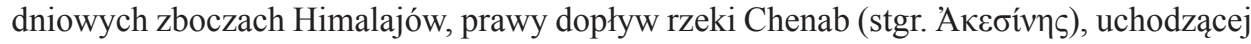
do Indusu. Nad jej brzegami dla uczczenia zwycięstw odniesionych w roku 326 p.n.e.

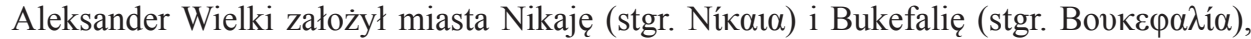
nazwaną tak na cześć Bucefała, dzielnego konia Macedończyka. W literaturze rzymskiej używano nazwy rzeki Hydaspes na określenie całej Indii. Por. Horatius, Carmina, I, 22, 8.

48 Lukan dwukrotnie wspomina rzekę Hydaspes w swoim dziele pt. Wojna domowa. W jednym fragmencie poeta odnotowuje rzekę Hydaspes jako dopływ Indusu (Bell. civ. III, 236): „Indus aquis mixtum non sentit Hydaspen” („Indus [...] Przy obfitości wód własnych Hydaspesa dopływu nie czuje"). Zob. Marek Anneusz Lukan, Wojna domowa, tł. i oprac. M. Brożek, Kraków 1994, 59. W drugim fragmencie zaś (VIII, 227) Lukan obdarza rzekę epitetem Nysaeus ('nysejski'), utworzonym od nazwy miasta Nysa leżącego nad Indusem. 
13. Arar (Araris) to rzeka na Wschodzie ${ }^{49}$, o której pisze Wergiliusz ${ }^{50}$ : Aut Ararim Parthus bibet ('Albo Part będzie pić wodę z Araru') ${ }^{51}$. Płynie bowiem przez Partię i Asyrię 52 .

14. Twierdzi się, że Baktros (Bactrus) $)^{53}$, rzeka płynąca na Wschodzie, została nazwana od króla Baktrosa, który użyczył swego imienia również Baktrianom i ich miastu ${ }^{54}$.

49 Arar był w rzeczywistości rzeką Galii, identyfikowaną z dzis. Saoną (fr. Saône), rzeką południowej części Francji, mającą początek w Wogezach. Saona uchodzi do Rodanu w okolicach Lyonu. Zob. R. de Félice, Les noms de nos rivières. Leur origine. Leur signification, Paris 1906, 91-93; E. Kaczyńska, Glosy obcojęzyczne w dziele PseudoPlutarcha De Fluviis, „Meander” 68 (2013) 56. Prawidłową lokalizację rzeki podaje: Vibius Sequester, De fluminibus, fontibus, lacubus, nemoribus, paludibus, montibus, gentibus per literras libellus, 2: „Arar, Germaniae, e Vogeso monte. miscetur Rhodano. ita lene decurrit, ut vix intellegi possit decursus eius".

50 Por. Vergilius, Eclogae, I, 62.

51 Cytowany fragment Wergiliusza pochodzi z dłuższego passusu zawierającego figurę retoryczną zw. adynaton (rodzaj hiperboli), która polega na wyliczeniu rzeczy niemożliwych (adynata) dla wzmocnienia stawianej w porównaniach tezy (Ecl. I, 59-63): „Ante leves ergo pascentur in aethere cervi / et freta destituent nudos in litore pisces, / ante pererratis amborum finibus exsul / aut Ararim Parthus bibet aut Germania Tigrim, / quam nostro illius labatur pectore vultus" ("Wpierw więc chyże jelenie w obłokach będą się pasły, / Ryby zaś morza toń opuszczone na brzegu zostawi, / Wpierw po cudzych dziedzinach błąkając się, z dala od własnych, / Party pić będą z Araru, Germany zaś z nurtów Tygrysu, / Niżby się w moim sercu zaćmiło jego oblicze'). Zob. Wergiliusz, Bukoliki $i$ Georgiki (wybór), tł. Z. Abramowiczówna, Wrocław 1953, 7.

52 Izydor z Sewilli na skutek błędnej interpretacji Wergiliuszowej frazy zlokalizował rzekę Arar na terytorium Partii i sąsiadującej Asyrii. Nie można jednak wykluczyć, że biskup z Sewilli powielił błąd zawarty w jakimś nieznanym nam źródle, z którego korzystał.

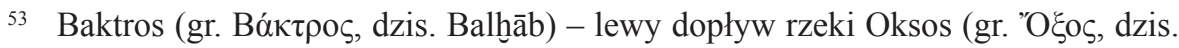
Amu-daria), mający źródła na górze Paropamisos (dzis. Hindukusz). Rzeka identyfikowana przez Arystotelesa (Mete. I, 13, 16) i Pseudo-Plutarcha (Defluv. XXIII, 1) z Araksesem, kończącym swój bieg w Morzu Kaspijskim.

${ }^{54}$ Chodzi o miasto Bactra (dzis. Balkh), znane wcześniej pod nazwą Zariaspa, leżące w Baktrii na Jedwabnym Szlaku, drodze handlowej łączącej Daleki Wschód z Morzem Śródziemnym. Św. Izydor w innym miejscu Etymologii (XV, 1, 11) mówi o odhydronimicznym pochodzeniu ojkonimu: „Bactrum oppidum Bactriani condiderunt, ex proprio amne eum cognominantes, qui Bactros vocatur". Ten sam wywód znajdujemy u Kurcjusza Rufusa (Hist. Alex. Magn. VII, 4, 31), Pliniusza Starszego (Nat. hist. VI, 48) i Solinusa (Coll. XLIX, 1). 
15. Choaspes (Choaspis) ${ }^{55}$ jest rzeką Persów, która w ich języku została tak nazwana ze względu na niezwykłą słodycz wody. Z tego powodu królowie perscy domagali się kubków z wodą z tej właśnie rzeki pod warunkiem, że płynęła ona jeszcze $\mathrm{w}$ granicach Persji ${ }^{56}$. Zdaniem niektórych, z tego cieku bierze swój początek Kydnos, rzeka Cylicji ${ }^{57}$.

16. Arakses (Araxis) $)^{58}$ to rzeka w Armenii, która bierze początek na tej samej górze co Eufrat, ale w przeciwieństwie do niego płynie innym podziemnym kanałem. Rzeka została nazwana Arakses, ponieważ z powodu gwałtowności (rapacitate) ${ }^{59}$ wszystko niszczy. Stąd gdy Aleksander Wielki chciał się przez nią przeprawić i nakazał zbudować most, ta tak gwałtownie podniosła stan wody, że go zerwała. Arakses tworzy się W niewielkiej odległości od źródła Eufratu i stamtąd wpada do Morza Kaspijskiego ${ }^{60}$.

55 Choaspes (gr. Xoó $\pi \eta\rceil$, dzis. Karkheh a. Karkhen w Iranie) - lewy dopływ Tygrysu, płynący przez perską prowincję Suzjanę. Na jej wschodnim brzegu leżały Suzy, stolica państwa perskiego, założona przez króla Dariusza I. Rzeka słynęła z czystej, krystalicznej wody. Herodot (Hist. I 188) informuje, że król Cyrus II Wielki na wszystkie wyprawy wojenne woził ze sobą w srebrnych naczyniach przegotowaną wodę z rzeki Choaspes. Również Kserkses pił wodę wyłącznie z rzeki Choaspes (Aelianus, Varia historia XII 40). Postać Xoá $\sigma \pi \eta \varsigma$ jest grecką adaptacją perskiego hydronimu urobionego od przymiotnika złożonego hvaspā- f. '(mający) dobrą wodę'. Por. hu- ('dobry') i aspā('woda') oraz łac. aqua f. 'ts.' Zob. J. Rozwadowski, Studia nad nazwami wód stowiańskich, Kraków 1948, 179.

56 Por. Solinus, Collectanea rerum memorabilium, XXXVIII, 4.

57 Informacja błędna, zob. przyp. 67. Por. Solinus, Collectanea rerum memorabilium, XXXVIII, 4: „Hunc Cydnum alii praecipitari Tauro, alii derivari ex alveo Choaspi tradiderunt".

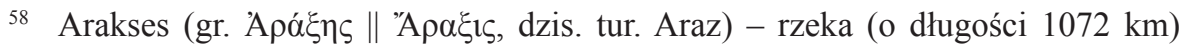
w Armenii (obecnie w Turcji, Armenii, Iranie i Azerbejdżanie), uchodzi do Morza Kaspijskiego. Arakses wypływa z gór Bingöl Dağları (dosł. 'góry tysiąca jezior') w Turcji, z których bierze początek również potok źródłowy Eufratu Murat Nehri (a. Murat Su). Ciek stanowi obecnie prawy dopływ rzeki Kury (łac. Cyrus, gr. Kõpos), która w starożytności wpadała do morza osobną deltą. Współcześni badacze akceptują starożytną etymo-

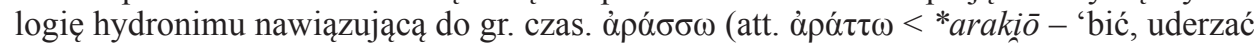

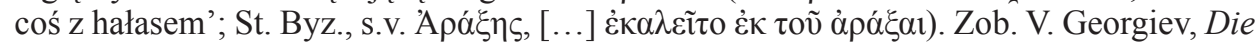
altgriechischen Flussnamen, Sofia 1958, 8-9. Tischler (Kleinasiatische Hydronymie, s. 31) uważa ten wywód za rzadki przykład poprawnej etymologii antycznej.

59 Izydor błędnie kojarzy nazwę rzeki Araxis z łacińskim apelatywem rapacitas $\mathrm{f}$. ('skłonność do porywania, zagarniania') < rapax adi. ('gwałtownie chwytający, porywający') < czas. rapere ('chwytać i unosić ze sobą, porywać, zabierać').

60 Por. Solinus, Collectanea rerum memorabilium, 86, 4-5: „Araxes brevibus intervallis ab Euphratis ortu caput tollit ac deinde in Caspium fertur mare". 
17. Syryjska rzeka o nazwie Orontes ${ }^{61}$ płynie w pobliżu murów Antiochii; wypływa na wschodzie (a solis ortu oriens), następnie wpada do morza [Śródziemnego] niedaleko miasta. Starożytni po łacinie nazwali rzekę Orontes od miejsca jej pochodzenia (de originis suae tractu) ${ }^{62}$. Całe miasto [tj. Antiochię] niemal bez przerwy orzeźwia wiejący od zachodu wiatr oraz strumienie chłodnego powietrza znad szybko płynącej rzeki.

18. Jordan ${ }^{63}$ (Iordanis), rzeka w Judei, zawdzięcza swe miano dwu źródłom, z których jedno nosi nazwę Jor, drugie zaś - Dan ${ }^{64}$. Po połączeniu

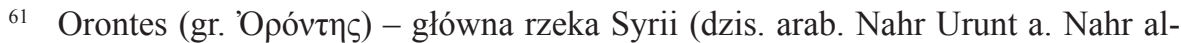
'Âșī, dosł. 'rzeka drapieżna, zdolna do porywania', tur. Asi Nehri), mająca swe źródła na górze Liban, niedaleko Heliopolis (dzis. Baalbek). Rzeka (o długości $450 \mathrm{~km}$ ) płynie doliną Celisyrią (dzis. Bekaa) pomiędzy Libanem i Antylibanem, mija Emesę (dzis. Ḥims w Syrii), Epifaneję (dzis. Hamāh w Syrii) i Antiochię (dziș. Antakya w Turcji), stolicę hellenistycznego państwa Seleucydów. Uchodzi do Morza Śródziemnego na pd. od pieryjskiej Seleucji (dzis. Çevlik, koło miasta Samandağ), portu Antiochii, leżącej od niej w odległości $25 \mathrm{~km}$. Rzeka płynie obecnie przez Liban, Syrię i Turcję.

${ }_{62}$ Rzeka Orontes już w IX wieku p.n.e. jest znana Asyryjczykom pod nazwą Arantu. Egipcjanie z kolei używali miana Araunti. Wydaje się wielce prawdopodobne, że nazwa

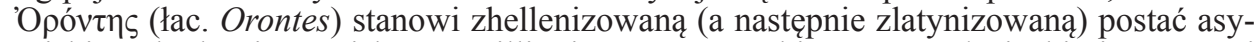
ryjskiego hydronimu. Biskup Sewilli wiąże nazwę rzeki Orontes z łacińskimi wyrazami oriri ('podnieść się, powstać, wschodzić, pochodzić, zaczynać się') i solis ortus ('wschód słońca'), wskazującymi na rejon występowania analizowanego cieku. Należy odnotować, że nazwa wodna Orontes nie doczekała się przekonującego objaśnienia. Zob. Tischler, Kleinasiatische Hydronymie, s. 110; R. Faure Sabater, Diccionario de nombres geográficos y étnicos del mundo, Madrid 2004, 448.

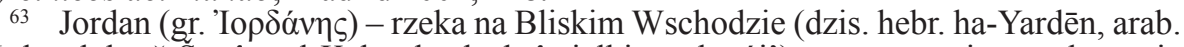
al-Urdun lub aš-Sarīeat al-Kabīrah, dosł. 'wielki wodopój’), tworząca się z połączenia czterech potoków źródłowych (Hasbani, Banias, Dan, Ajun) na pd. zboczach Antylibanu (ze szczytem Hermon - 2814 m). Obecnie płynie przez Liban, Syrię, Izrael oraz Jordanię. Rzeka (o długości $251 \mathrm{~km}$ ) przepływa przez dolinę Hula (wyschnięte biblijne Jezioro Semechonitis), Jezioro Tyberiadzkie (bibl. Jezioro Galilejskie lub Genezaret), silnie meandruje w dolnym biegu, wreszcie uchodzi deltą do Morza Martwego (ant. Jezioro Asfaltowe, łac. lacus Asphaltites), słonego jeziora położonego 394 metry poniżej poziomu morza. Nazwę rzeki językoznawcy-semitolodzy wywodzą od rdzenia czasownikowego aram. $r d y$ ('schodzić, płynąć') lub hebr. yrd 'ts.'. Zob. K. Bieberstein, Iordanes, w: Brill's New Pauly: Encyclopedia of Ancient World, vol. 6, red. H. Cancik - H. Schneider - M. Landfester, Leiden - Boston 2005, 918-919. Istnieje również hipoteza badawcza zakładająca indoeuropejskie pochodzenie potamonimu. Por. apelatyw ie. *dānu- ('rzeka'), poświadczony w takich nazwach wodnych jak Dunaj (łac. Danubius), Rodan, Don, Eridanos etc. Zob. Faure Sabater, Diccionario, s. 331. Nie można wykluczyć, że palestyński hy-

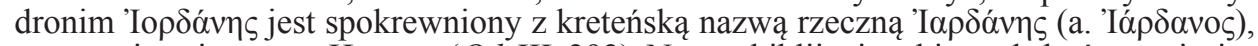
wspomnianą już przez Homera (Od. III, 292). Nazwa biblijnej rzeki mogła być przeniesiona z Krety przez Filistynów, którzy wedle źródeł hebrajskich pochodzili z wyspy Kaftor (tj. Krety). W przypadku kreteńskiej nazwy przyjmuje się, że początkowy człon 'I $\alpha \rho-$ kontynuuje indoeuropejski przymiotnik *isa rós ('silny, szybki'). Por. stind. ișiráh adi. 'ts.',

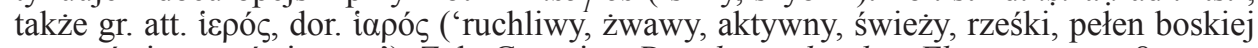
mocy, święty, poświęcony'). Zob. Georgiev, Die altgriechischen Flussnamen, s. 8.

64 O dwóch źródłach Jordanu pisał wcześniej św. Hieronim (Comm. in Matth. III, 16, 121-122, PL 26, 114-115): „Iordanis [...] habet duos fontes, unum nomine Ior et alterum Dan, qui simul mixti Iordanis nomen efficient”. Blisko źródeł Jordanu znajdowało się 
w jednym korycie dwu źródeł, które wytryskują w pewnym oddaleniu od siebie, rzeka przybiera nazwę Jordan. [Ciek] bierze początek u podnóża Góry Libańskiej65, płynie pomiędzy Judeą i Arabią, po zakreśleniu wielu zakoli uchodzi do Morza Martwego w pobliżu Jerycha.

19. Eusis ${ }^{66}$ wypływa z gór Kaukazu i z kilkoma innymi rzekami uchodzi do Morza Euksyńskiego (in Eusinum zam. Euxinum) ${ }^{67}$, któremu zresztą zawdzięcza swą nazwę.

20. Kydnos $(C y d n u s)^{68}$ to rzeka w Cylicji, wypływająca z góry Tauros, której wody charakteryzuje nadzwyczajna słodycz. Nosi taką nazwę, po-

miasto o nazwie Dan, stolica plemienia Izraelitów, wywodzącego się od biblijnego Dana, syna Jakuba (Izraela) i Bilhy.

65 Góra Libańska lub Liban (łac. mons Libanus, por. aram. laban - 'biały') to wysokie pasmo górskie $(3083 \mathrm{~m})$ oddzielone żyzną doliną Celesyrią (dzis. Bekaa) od Antylibanu, z którego początek bierze rzeka Jordan. Liban słynął w starożytności z lasów cedrowych.

${ }^{66}$ Ponieważ w starożytnych źródłach trudno znaleźć jakąkolwiek informację o rzece Eusis, możemy z dużą dozą prawdopodobieństwa założyć, że św. Izydor w rzeczywistości mówił o Fasis (łac. Phasis, gr. Фãбı)), kolchidzkiej rzece (o długości 327 km) znanej z wyprawy Argonautów po złote runo (dzis. Rioni w zachodniej Gruzji). Por. Ambrosius, Hexaemeron, II 3, 12, PL 14, 163: ,itemque de septentrionali parte Phasis Caucaseis montibus fusus cum pluribus aliis in Euxinum se praecipitans mare" ("Również ze stron północnych z gór Kaukazu płynie rzeka Fasis i z wielu innymi wpada do Euxinu [Morza Czarnego])'. Zob. Św. Ambroży, Hexaemeron, tł. W. Szołdrski, Warszawa 1969, 69). Źródła rzeki Fasis znajdują się w pd.-zach. części Kaukazu w regionie Racha. Ciek uchodzi do Morza Czarnego na pn. od miasta Poti (w pobliżu ant. Phasis). Do odkształcenia nazwy rzecznej doszło zapewne pod wpływem talasonimu (w wersji zacytowanej przez św. Izydora): Eusinum [scil. mare] > Eusis.

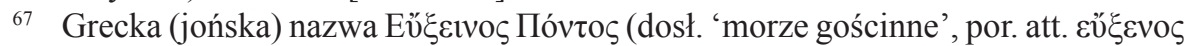
- 'gościnny') jest eufemistycznym określeniem Morza Czarnego, które w językach irańskich nazywano „ciemnym, niebieskim”. Por. aw. axšaēna- ('ciemnego koloru, ciemny'), stpers. axšaina ('błękitny, modry, siny') < iran. *axšaina- ('błękitny, modry, niebieski, zielony, szaroniebieski'). Grecy błędnie zinterpretowali irańską nazwę jako ’A $\xi є v o \varsigma$

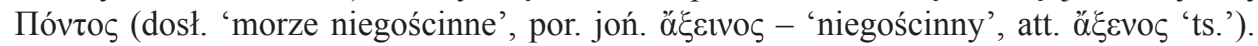
Zob. I. Fykias - Ch. Katsikadeli, Toponyms, w: Encyclopedia of Ancient Greek Language and Linguistics, t. 3, red. G.K. Giannakis, Leiden - Boston 2014, 416-417; P. Sobotka, Etymologizowanie i etymologia. Od semantyki ontologicznej do etymologii hermeneutycznej, Warszawa 2015, 173-175. Pomponiusz Mela tak wyjaśnia tę zmianę nazwy (Chor. I, 102): „Niegdyś nazwano je [tj. Morze Czarne] Aksejnos od dzikiego charakteru ludów nad nim mieszkających; otrzymało zaś nazwę Euksejnos, gdy wskutek stosunków handlowych charakter ten nieco się zmienił”. Zob. Pomponiusza Meli Chorografia czyli Opis kręgu ziemi, t1. M. Golias, Piotrków Trybunalski 2011, 71.

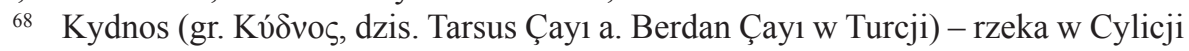
(o długości 124 km) ze źródłami w górach Taurus (dzis. Toros Dağları), pierwotnie płynąca przez miasto Tarsos. Po wielkiej powodzi, która dotknęła Tarsos, cesarz bizantyń- 
nieważ wszystko, co jest białe, Syryjczycy nazywają w swoim rodzimym języku cydnus. Stąd też takie miano zostało nadane tej rzece, gdyż przybiera ona latem, kiedy topnieją śniegi; w pozostałych porach roku jest niewielka i spokojna ${ }^{69}$.

21. Hylas ${ }^{70}$, rzeka w Azji. Paktolos (Pactolus) $)^{71}$, rzeka w Azji, niosąca złotonośne piaski, o której Wergiliusz [pisze] ${ }^{72}$ : Pactolusque inrigat auro ('I Paktolos nawadnia złotem'). Rzeka z uwagi na jej złoty nurt jest też nazywana Chrysorrhoas (dosł. 'tocząca złoto') ${ }^{73}$.

ski Justynian I (527-565) nakazał przesunąć koryto rzeki na wschód od miasta. Rzeka przed ujściem do morza tworzyła lagunę zwaną P̃̃ $\gamma \mu \alpha$ ('otchłań'), służącą za port Tarsos.

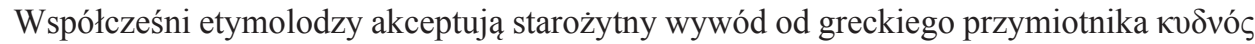
('sławny, znakomity') z charakterystyczną dla nazw proprialnych opozycją akcentu. Zob. Tischler, Kleinasiatische Hydronymie, s. 86. Wydaje się jednak, że hydronim Kúdvos po-

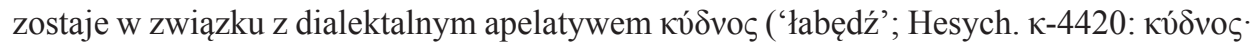

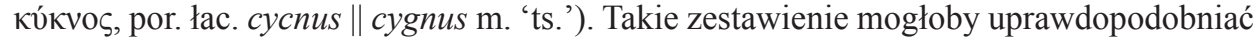
informację podaną przez św. Izydora z Sewilli, że nazwa wodna kryje w sobie nawiązanie do koloru białego (zob. też Solin, Coll. XXXVIII 5: „quidquid candidum est, cydnum gentili lingua Siri dicunt: unde amni huic [sc. Cydno] nomen datum"). W hydronimii europejskiej spotykamy wiele nazw wodnych związanych z białym kolorem. Por. stgr.

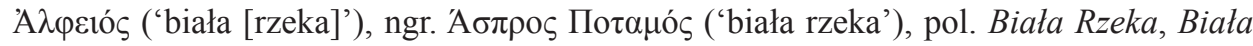
Struga, Biała Woda, hiszp. Guadalviar (< arab. wād̄̄ al-abyad, dosł. 'rzeka biała').

69 Por. Solinus, Collectanea rerum memorabilium, XXXVIII, 5: „Cydnus [...] tumet vere cum nives solvuntur, reliqua anni tenuis et quietus".

70 Hylas (gr. "Y $\lambda \alpha \varsigma$ ) - rzeka w Lidii (dzis. Kum Çayı, dosł. 'piaszczysta rzeka'), mająca źródła na górze Temnos (dzis. Simav Dağları). Uchodzi do rz. Hermos (dzis. Gediz Nehri) na pn.-wsch. od miasta Magnezja (dzis. Manisa), leżącego u stóp góry Sipylos (dzis. Spil Dağı). W starożytności rzeka obfitowała w ryby. Nazwę "Y $\lambda \alpha \varsigma$ uważa się za derywat urobiony sufiksem nazwotwórczym $-\bar{\alpha} \varsigma$ (m.) od gr. ap. $\tilde{\lambda} \lambda \eta$ f. ('szlam, muł, ił, błoto'). Por. vं $\lambda \omega ́ \delta \eta \varsigma$ adi. ('o rzece mętny, zamulony'). Zob. Tischler, Kleinasiatische Hydronymie, s. 64-65. W antycznych źródłach Hylas funkcjonuje też pod postacią "Y

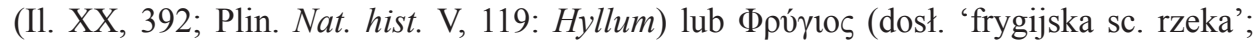
Strabon, Geogr. XIII 4, 5).

71 Paktolos (gr. П $\left.\alpha \kappa \tau \omega \lambda \varsigma_{\varsigma}\right)$ - niewielka rzeka w Lidii o długości 25 km, lewy dopływ rz. Hermos (dzis. Gediz Nehri). Bierze początek w górach Tmolos (dzis. Bozdağ). Rzeka przepływała przez Sardes (gr. $\Sigma a ́ \rho \delta \varepsilon ı \varsigma)$, dawną stolicę królestwa Lidii. Obecnie płynie w Turcji i nosi nazwę Sart Çayı, utworzoną od ojkonimu Sart (< ant. Sardes). W starożytności ciek obfitował w złote okruchy (wyeksploatowane w I wieku p.n.e.), którym lidyjscy królowie z rodu Mermnadów (od Gygesa po Krezusa) zawdzięczali swoje legendarne bogactwo. Antyczny hydronim pozostaje w związku z czas. $\pi \eta ́ \gamma v v \mu 1$ ('wbijać, mocować, utwierdzać').

72 Por. Vergilius, Aeneis, X, 142.

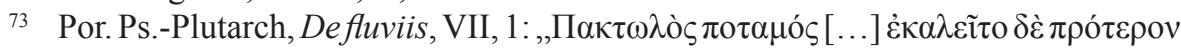

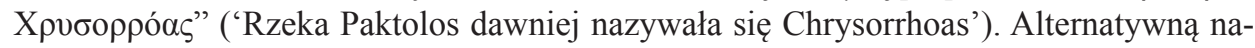
zwę rzeki przytaczają też Pliniusz (Nat. hist. V, 110) i Solinus (Coll. XL, 10). 
22. Hermos $(\text { Hermus })^{74}$ to rzeka w Azji, która przecina równinę smyrneńską̨ ${ }^{75}$. Jej fale toczą złotodajny piasek ${ }^{76}$. Hermosowi swoją nazwę zawdzięcza Smyrna ${ }^{77}$.

23. Meander ${ }^{78}$ to kręta rzeka, płynąca w Azji, która czyniąc zakola pomiędzy Karią i Jonią, wpada do zatoki oddzielającej Milet i Priene ${ }^{79}$.

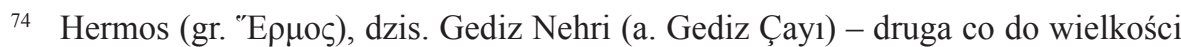
rzeka w Anatolii (o długości 401 km). Wypływa z gór Murat Dağ1 (ant. Dindymon, poświęcone frygijskiej bogini Kybele), płynie przez tureckie prowincje Kütahya i İzmir, uchodzi deltą do Zatoki Izmirskiej (ant. Zatoka Smyrneńska) na pd. zach. od wsi Maltepe (ok. 30 $\mathrm{km}$ na pn. zach. od Smyrny, dzis. İzmir). W starożytności państwo lidyjskie obejmowało całe dorzecze Hermosu. Uważa się, że hydronim, zapewne frygijskiego pochodzenia, powstał w wyniku derywacji dezintegralnej i paradygmatycznej od gr. ap. ह̌ $\rho \mu \alpha,-\alpha \tau o \varsigma$ n. ('podmorska skała, rafa, ławica piaskowa, mielizna'). Zob. Tischler, Kleinasiatische Hydronymie, s. 61-62. Etymologię tę potwierdza epitet $\pi \mathrm{o} \lambda v \psi \tilde{\eta} \varphi 1 \varsigma$ ('mający wiele kamyków, żwirowaty’), którym Herodot (Hist. I 55, 2) określa rzekę Hermos („Hermos żwironośny").

75 Na równinny teren występowania dorzecza Hermosu zwracają uwage Pliniusz (Nat. hist. V, 119: „A Zmyrna Hermus amnis campos secat”) oraz Solinus (Coll. XL, 15: „Zmyrnaeos vero campos Hermus secat").

76 Wergiliusz mówi o „Hermusie mętnym od złota” (Georg. II, 137: ,auro turbidus Hermus"). Por. Solinus, Collectanea rerum memorabilium, XL, 15.

77 Objaśnienie ojkonimu, przytoczone przez św. Izydora, należy uznać za błędne (zob. też Isid. Etym. XV, 1, 39: „vocata Smyrna quod eius campos Ermus fluvius secat”). Por. Solinus, Collectanea rerum memorabilium, XL, 16. Warto odnotować, że nazwę Smyrny w starożytności wywodzono, na zasadzie tzw. etymologii ludowej, od apelatywu $\sigma \mu v ́ \rho v \alpha(=\mu v ́ \rho \rho \alpha)$ f. ('mirra, drzewo balsamowe'), stanowiącego pożyczkę semicką. Zob. R. Rosół, Frühe semitische Lehnwörter im Griechischen, Frankfurt am Main 2013, 71-72.

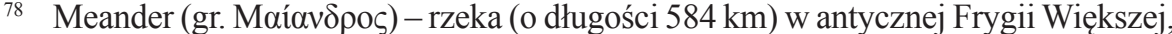
Karii i Jonii, wypływająca z okolic frygijskiego miasta Kelajnaj (dzis. Dinar). Obecnie płynie w pd.-zach. Turcji i nosi nazwę Büyük Menderes Nehri lub Büyük Menderes Irmağı ('Wielki Menderes' dla odróżnienia od Kücük Menderes Nehri - 'Mały Menderes'; ant. Kaystros w Lidii). Zob. D.J. Georgacas, The Names for the Asia Minor Peninsula and a Register of Surviving Anatolian Pre-Turkish Placenames, Heidelberg 1971, 116. Nazwa rzeczna jak dotąd nie doczekała sie przekonującego objaśnienia. Zob. Tischler, Kleinasiatische Hydronymie, s. 93-94. Część badaczy uważa hydronim za zhellenizowaną formę nazwy karyjskiej, lidyjskiej (obie pochodzenia anatolijskiego) lub frygijskiej, przywołując strukturalne podobieństwo nazwy Maiandros do obserwowanych na obszarze występowania tych trzech języków licznych ojkonimów z sufiksem -anda, np. Millawanda, Wijanawanda. Nie brakuje głosów mówiących o semickiej genezie nazwy rzecznej ( $<$ hebr. mayim pl. - 'wody', także me'yim - 'jelita, łono'). Niektórzy onomaści uważają za przekonujące zestawienie

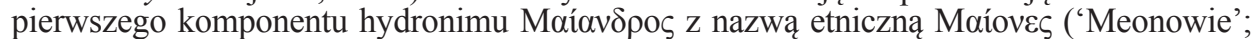
< gr. Maıovía f. - 'Meonia', dawna nazwa Lidii), zaproponowane przez V. Georgieva (Zur altkleinasiatischen Hydronymie, „Beiträge zur Namenforschung” 8 (1957) 158-159; V. Georgiev, Исследования по сравнительно-историческому языкознанию, Москва 1958, 171). Uważa się za nieprawdopodobne greckie pochodzenie potamonimu (teren, na którym płynie rzeka, nigdy nie był zamieszkany przez użytkowników języka greckiego). Rzeka we-

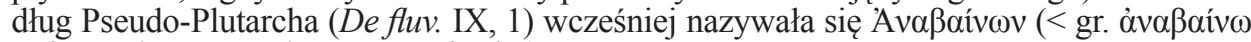
- 'iść pod górę, wezbrać, wznosić się').

79 Por. Solinus, Collectanea rerum memorabilium, XL, 8: „Meander [...] praecipitat in sinum, qui Miletum dividit et Prienam”. W starożytności rzeka uchodziła do Zatoki 
Meander został tak nazwany, ponieważ jest kręty i nigdy nie płynie w linii prostej ${ }^{80}$. O nim [pisze] Owidiusz: Curvis ludit Maeander in undis ${ }^{81}$ ('Meander, wśród krętej igrający drogi' $)^{82}$.

24. Twierdzi się, że rzeka Tanais ${ }^{83}$ zawdzięcza nazwę Tanusowi, pierwszemu królowi Scytów. Tanais wypływa z Lasu Ryfajskiego ${ }^{84}$, oddziela Europę od Azji, płynąc pośrodku, pomiędzy dwiema częściami świata ${ }^{85}$, i wpływa do Pontu (tj. Morza Czarnego) ${ }^{86}$.

Latmijskiej (Morze Ikaryjskie), dziś już nieistniejącej. Rzeka wpada obecnie do Morza Egejskiego niedaleko ruin antycznego Miletu.

80 Nazwa własna Meander już w starożytności uległa apelatywizacji, stając się rzeczownikiem pospolitym oznaczającym 'zakręt rzeki, zakole' lub 'ornament geometryczny’. Zob. F. Montanari, Vocabolario della lingua greca, Torino 2003, 1217.

${ }^{81}$ Zacytowany przez Izydora fragment Metamorfoz Owidiusza (II, 246) różni się nieco od wersji przekazanej nam przez kodeksy: „,...] recurvatis ludit Maeandro in undis". Zob. P. Ovidi Nasonis, Metamorphoses, red. R.J. Tarrant, Oxford 2004.

82 Zob. Owidiusz, Przemiany, tł. B. Kiciński, Wrocław 1953, 37.

83 Tanais (gr. Tóvoïৎ), dzis. Don - rzeka o długości 1970 km, stanowiąca w starożytności naturalną granicę pomiędzy Scytią a Sarmacją (Herodot, Hist. IV 21). Antyczna (sarmacko-scytyjska) nazwa rzeki jest zestawiana z awest. ap. dānu- f. ('rzeka, strumień'), skt. dá̀nu f. n. ('ciecz kapiąca, kropla, rosa, mgła'), oset. don ('woda, rzeka') > n. w. Don. Zob. P.A. Агеева, Происхождение имен рек и озер, Москва 1985, 85. Spółgłoska bezdźwięczna $t$ - w nagłosie hydronimu (zamiast $d$-) zdaniem badaczy wskazuje na zapożyczenie nazwy Tóvaïs od ludu indoeuropejskiego, w języku którego zachodziło ubezdźwięcznienie spółgłoski przedniojęzykowej $d>t$. Zob. Rozwadowski, Studia, s. 244.

84 Nie mamy żadnych informacji na temat Lasu Ryfajskiego (Riphaeae silvae). Znamy jednak z tego rejonu Góry Rypajskie lub Ryfajskie (łac. montes $R(h) i p(h) a e i$, rzadziej mons $R(h) i p(h) a e u s)$, określające pierwotnie mityczny łańcuch górski, wznoszący się gdzieś na dalekiej północy. Od wieku I n.e. zaczęto identyfikować Góry Rypajskie z górami Scytii (dzis. Ural), położonymi u źródeł rzeki Rha (dzis. Wołga). Maurus Serwiusz (Schol. in Georg. III, 382) wywodzi nazwę scytyjskich gór „od ciągłych podmuchów wia-

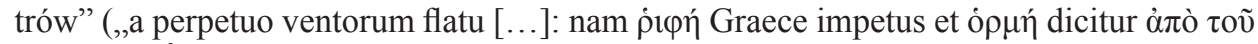
ṕí $\left.\tau \varepsilon v v^{\prime \prime}\right)$. Źródła Tanais na Górze Rifajskiej błędnie lokalizuje Pomponiusz Mela (Chor. I, 115: ,ipse Tanais ex Riphaeo monte deiectus”). W rzeczywistości rzeka wypływa z Wyżyny Środkoworosyjskiej na pd. od Moskwy.

85 Pomponiusz Mela (Chor. I, 15) w opisie Europy wskazuje rzekę Tanais jako wschodnią granicę kontynentu europejskiego.

86 Rzeka w rzeczywistości uchodziła od pn.-wsch. strony do Jeziora Meockiego (dzis. Morze Azowskie), oddzielonego od Morza Czarnego cieśniną zwaną Bosforem Kimeryjskim (dzis. Cieśnina Kerczeńska). 
25. Inachos ${ }^{87}$ jest rzeką w Achai ${ }^{88}$, nawadniającą równiny argolidzkie ${ }^{89}$, którą król Inachos ${ }^{90}$, protoplasta ludu argiwskiego, nazwał swoim imieniem. Tam (tj. w Achai) znajduje się także Erymant ${ }^{91}$, wypływający z Góry Erymanckiej ${ }^{92}$.

87 Chodzi o rzekę okresową płynącą w Argolidzie, krainie położonej w pn.-wsch.

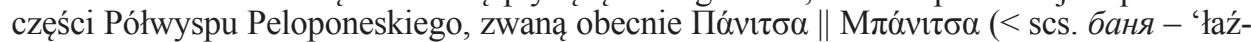

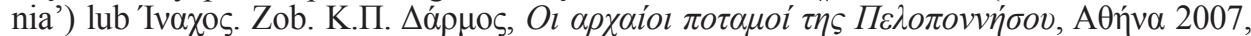
11-20. Inachos wypływa z góry Lírkio $(1755 \mathrm{~m})$, mija miasto Argos od wschodu, kończy bieg w Zatoce Argolidzkiej (Morze Egejskie), na zach. od miasta portowego Náfplio. Zimą rzeka często wylewa, podczas gdy latem całkowicie wysycha. Rzeka Inachos pojawia się po raz pierwszy w tragediach Eurypidesa (El. 1; Suppl. 645, 890; Phoen. 574). Pseudo-

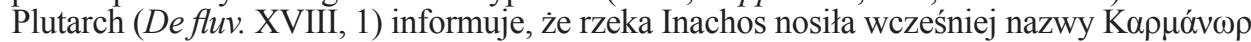
i A $\lambda \imath^{\prime \alpha ́ k \mu \omega v . ~ Z o b . ~ P l u t a r c o, ~ F i u m i ~ e ~ m o n t i, ~ i n t r o d u z i o n e, ~ t e s t o ~ c r i t i c o, ~ t r a d u z i o n e ~ e ~ c o m m e n-~}$ to, red. E. Calderón - A. De Lazzer - E. Pellizer, Napoli 2003, 179-181, 240 (przyp. 144).

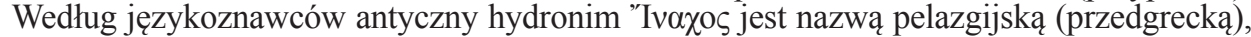
stanowiącą formację złożoną o znaczeniu 'tryskająca woda / eau jaillissante' lub 'szybka woda / schnelles Wasser'. Por. skt. iṣnắti ('porusza się szybko'), gr. ìvó $\omega$ \| ivé czać, wypróżniać') i ie. *akwā ('woda', z końcówką -o $\mathrm{w}$ nazwie wodnej pod wpływem

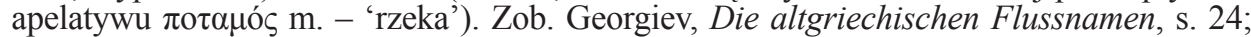
V. Georgiev, Die Herkunft der Namen der grössten Flüsse der Balkanhalbinsel und ihre Bedeutung zur Ethnogenese der Balkanvölker, „Linguistique Balkanique” 1 (1959) 8. Warto odnotować, że inna rzeka o tej samej nazwie (dopływ Sperchejosu), płynaca w pd. Tesalii

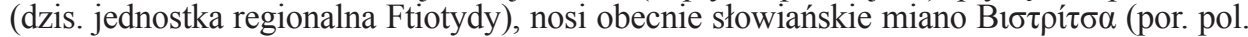
Bystrzyca). Zob. M. Vasmer, Die Slaven in Griechenland, Lepzig 1970, 103.

88 Nazwą Achaja (łac. Achaea) określano prowincję rzymską utworzoną po podboju Grecji przez Rzymian w roku 146 p.n.e. Z czasem (tj. od 26 p.n.e.) Achaja stała się odrębną prowincją $\mathrm{z}$ ośrodkiem administracyjnym w Koryncie.

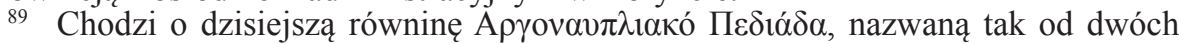
miast Argos i Náfplio, obecnej stolicy jednostki regionalnej Argolidy.

90 Por. Solinus, Collectanea rerum memorabilium, VII, 10: „Inachus Achaiae amnis [...], quem rex Inachus a se nominavit"; Hieronymus, Chronica, II (ab Abrah. 161), PL 27, 267-268: ,,a patre Inacho Inachus fluvius apud Argos [...] nuncupatur”. Według wersji przekazanej przez Pseudo-Plutarcha (De fluv. XVIII, 1), Inachos był synem Okeanosa, ojcem Io, argiwskiej kapłanki, uwiedzionej przez Dzeusa. Dotknięty zniewagą ojciec obrzucił obelgami najwyższego boga, za co spotkała go surowa kara. Inachos opętany przez Tisifonę, jedną z Erynii, którą nasłał nań Dzeus, zakończył żywot w nurtach rzeki Haliakmon, nazywanej odtąd na jego cześć Inachosem.

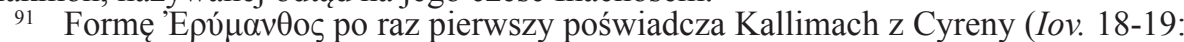

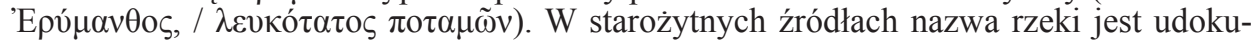

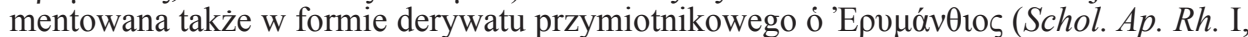

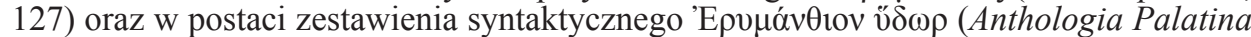

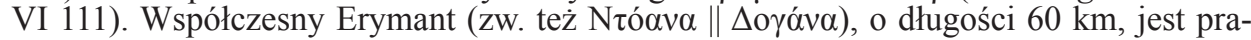
wym dopływem Alfejosu, największej rzeki $(120 \mathrm{~km})$ Półwyspu Peloponeskiego. Zob.

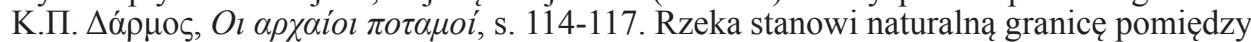
dzisiejszymi regionami Peloponezu i Grecji Zachodniej. Bierze początek na pd.-wsch.

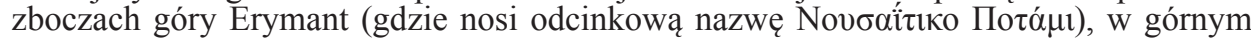

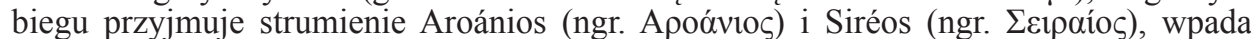
do Alfejosu nieco na zachód od innej słynnej rzeki Ladon (stgr. $\Lambda \alpha ́ \delta \omega v$, ngr. $\Lambda \alpha ́ \delta \omega v \alpha \varsigma$ ).

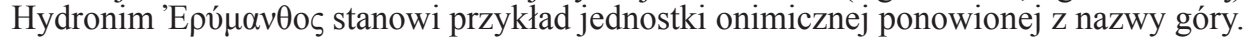

92 Masyw górski wznoszący się w Arkadii na granicy z Elidą (obecnie na granicy dwu jednostek regionalnych Achai i Elei), znany dzisiaj pod starożytną nazwą 
26. $\mathrm{Pad}^{93}$ to rzeka w Italii, która spływa urwistymi zboczami Alp, biorąc swój początek z trzech źródeł. Jedno z nich, określane nazwą Padus, rozlewa się, tworząc rodzaj jeziora, skąd niczym z łona wypływa rzeka. Temu właśnie źródłu Pad zawdzięcza swoją nazwę ${ }^{94}$. Grecy określali rze-

Epú $\mu \alpha v \theta$ os lub nowożytną $\Omega \lambda$ ovós $\| \Omega \lambda \varepsilon v o ́ \varsigma$ (określającą najwyższy szczyt $-2224 \mathrm{~m}$ ). Najwcześniejsze atestacje nazwy góry sięgają epoki mykeńskiej. Oronim pojawia się na tabliczkach pylijskich, zapisanych pismem linearnym $\mathrm{B}, \mathrm{w}$ formie o-ru-ma-to (PY $\mathrm{Cn}$

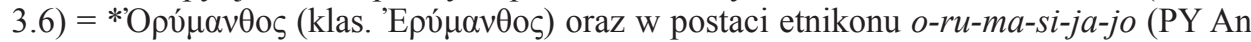

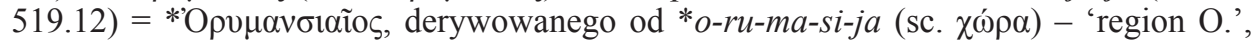
utworzonego z kolei od toponimu o-ru-ma-to. Zob. F. Aura Jorro, Diccionario Micénico, t. 2, Madrid 1993, 50-51. Vladimir Georgiev (Die altgriechische Flussnamen, s. 21) uważa nazwę góry 'O $\rho$ $u \alpha v \theta$ os za pelazgijską i wywodzi od ie. *uru-monto-s ('rozległa góra

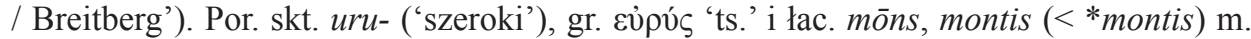
('góra'). Wedle starogreckich wierzeń w okolicach Erymantu grasował olbrzymi dzik erymancki, którego pojmanie żywcem stanowiło jedną z dwunastu prac Heraklesa.

93 Pad (wł. Po) - największa rzeka we Włoszech (o długości 652 km), bierze swój początek w prowincji Cuneo w Alpach Kotyjskich (w Piemoncie) w miejscu zw. Pian del Re (2020 m). Płynie m.in. przez Turyn, Piacenzę, Cremonę, uchodzi do Morza Adriatyckiego szeroką deltą (złożoną z 5 głównych ramion) na pd. od Chioggio. Za główne ujście uważa się ramię wpadające na wsch. od miejscowości Pila, zwane Po della Pila.

94 Pliniusz Starszy (Nat. hist. III, 122), powołując się na Metrodora ze Skepsis, podaje, że rzeka Pad została nazwana od sosen rosnących u jej źródła, które w języku Gallów nazywają się padi (pl.). Zob. K.T. Witczak, Gaulish pados 'pitch-pine' and Lithuanian kadagỹs 'juniper', „Studia Indogermanica Lodziensia” 2 (1998) 171. Por. Gajusz Pliniusz Sekundus, Historia naturalna, t. 1: Kosmologia i Geografia. Księgi II-VI, tł. I. Mikołajczyk et alii, Toruń 2017, 259. Rzymski encyklopedysta nie omieszkał też przytoczyć niezwykle cenną informację, że Ligurowie, mieszkańcy górnego biegu rzeki, określali Pad rodzimym mianem Bodincus, co po łacinie miało znaczyć fundo carens ('pozbawiona dna', tj. głęboka). Zob. Plin. Nat. hist. III, 122. Antyczne objaśnienie potwierdzają nowożytni badacze, którzy uznają nazwę Bodincus za formację derywowaną ,liguryjskim” sufiksem -inko od rdzenia ie. *bhedh- ('kłuć, żgać, ryć, kopać'). Por. łac. fodio ('kopać, kłuć')

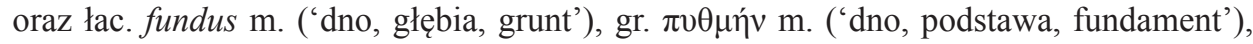
skt. budhná- m. / n. ('grunt, dno'), niem. Boden m. ('gleba, ziemia, grunt, dno'). Zob. C. Marcato, Po, w: Dizionario di toponomastica. Storia e significato dei nomi geografici italiani, red. G. Gasca Queirazza et alii, Torino 2005, 501. Istnieje hipoteza, jak dotąd słabo uargumentowana, zakładająca związek łac. Padus z liguryjskim hydronimem Bodincus. Zob. A. Renzo, Nomi d'Italia. Origine e significato dei nomi geografici e di tutti i comuni, Novara 2009, 296-297. Zdaniem niektórych językoznawców z hydronimem Padus spokrewniona jest nazwa Padwy (wł. Padova, łac. Patavium), miasta w pn.-wsch. Włoszech. Zob. G.B. Pellegrini, Toponomastica italiana. 10000 nomi di città, paesi, frazioni, regioni, contrade, fiumi, monti spiegati nella loro origine e storia, Milano 2008, 138-142; A. Ferrari, Dizionario del luoghi del mito. Geografia reale e immaginaria del mondo classico, Milano 2011, 726. 
kę Pad mianem Eridanos (Eridanus) ${ }^{95}$, utworzonym od Eridanosa, syna Słońca, którego nazywano też Faetonem ${ }^{96}$. Ten, rażony piorunem, spadł do tej właśnie rzeki i utonął ${ }^{97}$. Wraz ze wschodem „Psiej Gwiazdy”98 [rzeka] od topniejącego śniegu przybiera, a po przyjęciu trzydziestu innych rzek ${ }^{99}$ wpływa do Morza Adriatyckiego w pobliżu Rawenny ${ }^{100}$.

27. Tyber (Tiberis) ${ }^{101}$, rzeka w Italii, podobno otrzymała nazwę po Tyberinie, królu Albańczyków, który w niej utonął [podczas przeprawy] ${ }^{102}$.

95 Największa we Włoszech rzeka znana była w starożytnej Grecji pod nazwą

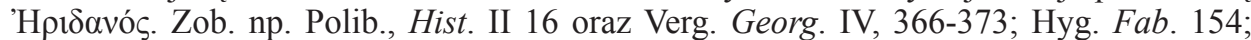
Plin. Nat. hist. III, 117; Solin. Coll. II, 25. Hezjod (VIII/VII wiek p.n.e.) w Teogonii wśród bóstw rzecznych, będących dziećmi pary tytanów Okeanosa i Tetydy, wymienia „Erydana

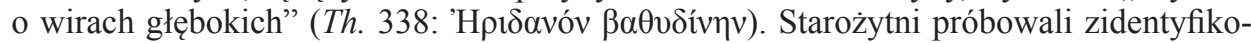
wać mityczny ciek z jakąś rzeczywistą rzeką, płynącą gdzieś na Zachodzie. Znane są próby zestawienia Eridanu z Renem, Rodanem, wreszcie Padem. Z terenu Grecji znamy słynny strumień o tej samej nazwie, prawy dopływ rzeki Ilissos, przepływający przez

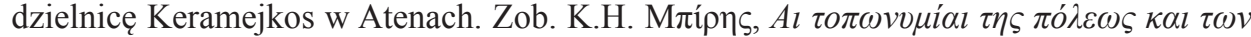

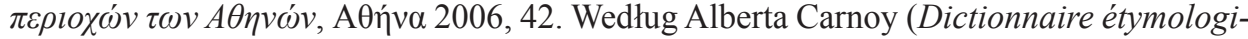

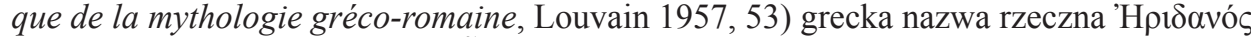
jest formacją złożoną z gr. ep. ஸ̃ pı adv. ('rano, wcześnie') i indoeuropejskiego rdzenia hydrograficznego $*$ danu-, poświadczonego chociażby w awestyjskim ap. dānu- f. ('rzeka, strumień'). Należy podkreślić, że hydronim 'H związku z takimi nazwami rzek, jak: Rodan, Dunaj, Dniepr, Dniestr, Don, Jordan. Zob. Faure Sabater, Diccionario, s. 199, 476.

96 Por. też Servius, Commentarii in Vergilii Aeneidos libros, VI, 659: „Eridanus Solis filius [...] fulminatus in Italiae fluvium cecidit: at tunc a luce ardoris sui Phaethon appellatus est, et pristinum nomen fluvio dedit".

97 Historię brawurowej jazdy Faetona rydwanem Heliosa opowiada obszernie m.in. Owidiusz (Met. II, 150-328)

98 Terminem „Psia Gwiazda” określa się Kanikułę, tj. Syriusza, najjaśniejszą gwiazdę w konstelacji Wielkiego Psa (łac. Canis Maior), zwiastującą letnie upały (22 VI-23 VIII).

99 Informację tę podaje już Pliniusz Starszy (Nat. hist. III, 118). W rzeczywistości Pad posiada ponad 140 dopływów.

100 Wody Padu w starożytności doprowadzone były do Rawenny tzw. kanałem Augusta (Augusta fossa). Ten ujściowy odcinek rzeki nosił nazwę Padusa (wcześniej Messanicus). Warto odnotować, że Rawenna leży ok. 60 km poniżej południowego krańca rozległej delty rzeki Pad.

101 Tyber (wł. Tevere) - niewątpliwie najsłynniejsza rzeka Włoch (o długości 405 km), wypływa ze zboczy góry Fumaiolo (leżącej w Apeninach Toskańskich), przepływa przez Rzym, wpada do Morza Tyrreńskiego w pobliżu Ostii i Fiumicino. Niektórzy badacze uważają, że rzeka w starożytności nosiła etruską nazwą Rumon, od której z dużym prawdopodobieństwem mógł zostać urobiony ojkonim Roma. Zob. Faure Sabater, Diccionario, s. 505, 569; C. Marcato, Nomi di persona, nomi di luogo. Introduzione all'onomastica italiana, Bologna 2009, 109.

102 Por. Varro, De lingua Latina, V, 30: Tiberinus, qui [...] nomen flumini dedit (Liv. I, 3, 8; Ov. Met. XIV, 614; Ov. Fast. IV, 47). Zob. też Ferrari, Dizionario del luoghi del 
Przed tym zdarzeniem rzeka nosiła starożytne miano Albula $^{103}$, utworzone od koloru, ponieważ [czasami] jest ona biała od śniegu ${ }^{104}$. Niekiedy rzeka Tiberis nazywana jest Tibris. [Trzeba jednak wiedzieć, że] w języku potocznym używa się nazwy Tiberis, forma Tibris pojawia się jedynie w poezji ${ }^{105}$.

28. Rzeka Danubius (Dunaj) ${ }^{106}$, wedle powszechnego mniemania, zawdzięcza nazwę olbrzymim pokładom śniegu (copia nivium) ${ }^{107}$, dzięki którym jeszcze bardziej przybiera. Dunaj spośród wszystkich rzek Europy cieszy się największą sławą. Znany jest też pod alternatywnym mianem Ister ${ }^{108}$, ponieważ zmienia swą nazwę $\mathrm{z}$ uwagi na fakt, iż biegnie przez

mito, 919-921. Objaśnienia nazw geograficznych od eponimicznych bohaterów lub bogów było niezwykle popularne w antycznej kreacji nazwotwórczej. Współcześnie nazwę Tybru

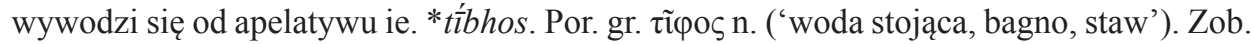
K.T. Witczak, The Latin Origin of the River Name Tiberis, „Latomus: Revue d'études latines" 73 (2014) z. 1, 3-10.

103 Por. Varro, De lingua Latina, V, 30: „sunt qui Tiberim priscum nomen Latinum Albulam vocitatum litteris tradiderint”; Vergilius, Aeneis, VIII, 330-332: „tum reges asperque immani corpore Thybris, / a quo post Itali fluvium cognomine Thybrim / diximus; amisit verum vetus Albula nomen”; Livius, Ab Urbe condita I, 3, 8: „fluvius Albula, quem nunc Tiberim vocant”; Plinius, Naturalis historia, III, 53: „Tiberis, antea Thybris appellatus et prius Albula".

104 Starożytni przeważnie wiązali hydronim Albula z kolorem wody. Zob. Sextus Pompeius Festus, De verborum significatione, 4 (Müller): „Albula Tiberis fluvius dictus est ab albo aquae colore".

$105 \mathrm{~W}$ postaci synkopowanej jest poświadczona jedynie forma Thybris, użyta m.in. przez Wergiliusza (Aen. VIII, 330-332: „Thybris, / a quo post Itali fluvium cognomine Thybrim / diximus”), a także przez Pliniusza Starszego (Nat. hist. III, 53: „Tiberis, antea Thybris appellatus").

106 Rzeka Dunaj (o długości 2888 km) wypływa z gór Schwarzwaldu (6 km na pn. zach. od Furtwangen), przepływa przez 10 krajów europejskich (Niemcy, Austrię, Słowację, Węgry, Chorwację, Serbię, Bułgarię, Rumunię, Mołdawię i Ukrainę), uchodzi do Morza Czarnego trzema głównymi ramionami: Kilia (od nazwy ukr. miasta Кілія < gr. biz. $\kappa \varepsilon \lambda \lambda i ́ \alpha$ n. pl. - 'spichlerze'), Sulina (tur. < rum. salina - 'miejsce pozyskiwania soli') i Sfântu Gheorghe ('Święty Jerzy’).

107 Kolejny przykład etymologii ludowej: Danubius < nivium copia. Obecnie nazwę Dunaju wywodzi się od pie. rdzenia *dhenH- ('płynąć'), poświadczonego w awestyjskim apelatywie dānu- ('rzeka, strumień'). Zob. Georgiev, Die Herkunft der Namen, s. 5; Faure Sabater, Diccionario, s. 199-200.

${ }^{108}$ Dunaj w dolnym biegu nosił nazwę Hister, Ister (gr. ’I $\sigma \tau \rho \circ \varsigma$ ). Por. Hesiodus,

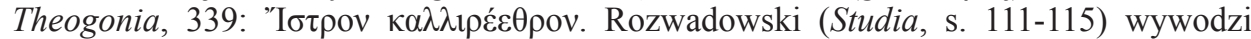
tracki hydronim ’I $\sigma \tau \rho \varsigma$, podobnie jak i nazwę Istra, określającą cztery rzeki Europy Środkowowschodniej, od rdzenia pie. *eish_-, rozszerzonego sufiksem *-ro- lub jego żeńską formą $*_{-} r \bar{a}-$. W nazwach tych (po zaniku laryngalnej ${ }^{*} h_{l}$ ) pojawia się epentetyczna 
niezliczone kraje; płynąc zaś coraz dalej, rozszerza się od naporu wody. Rzeka bierze początek w górach Germanii i w zachodnich rejonach, zamieszkałych przez barbarzyńców ${ }^{109}$, płynie następnie w kierunku wschodnim, przyjmując sześćdziesiąt dopływów, wreszcie uchodzi do Pontu (tj. Morza Czarnego) siedmioma ujściami (tj. rozbudowaną deltą).

29. Rodan (Rhodanus) ${ }^{110}$, rzeka w Galli, nazwana tak od miasta Rodos, założonego przez kolonistów rodyjskich ${ }^{111}$. Płynąc gwałtownym nurtem, przecina wody Morza Tyrreńskiego ${ }^{112}$. To zmieszanie się wody rzecznej z falami słonego morza stwarza często niemałe zagrożenie dla żeglarzy ${ }^{113}$.

spółgłoska -t-. Pokrewne nazwy, aczkolwiek nienotujące epentezy, pojawiają się w hydronimii zachodniej i północno-wschodniej Europy, np. gal. Isara, fr. Isère, niem. Iser (< celt. *Isarā), lit. Eisrà itd. Identyczną etymologię podaje Georgiev (Die altgriechischen Flussnamen, s. 24), a także Pokorny (Indogermanisches, s. 299-301). Obydwaj językoznawcy wywodzą tracką nazwę ”I $\sigma \tau \rho o \zeta$ od praformy *Is-ro-s < pie. *isa rós ('szybki,

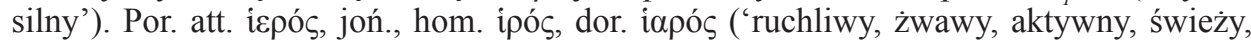
rześki, pełen boskiej mocy, święty, poświęcony').

109 Por. Ambrosius, Hexaemeron, II, 3, 12, PL 14, 163: „Danubius de occidentalibus partibus Barbarorum atque Romanorum intersecans populos, donec Ponto ipse condatur" ('Dunaj, płynąc z zachodu, przecina ziemie barbarzyńców i Rzymian i kryje się dopiero w Poncie (Morzu Czarnym)". Zob. Św. Ambroży, Hexaemeron, tł. W. Szołdrski, Warszawa 1969, 69.

${ }_{110}$ Rodan (fr. Rhône) - rzeka o długości 812 km, bierze początek w Alpach Urneńskich (Szwajcaria), przepływa przez Jezioro Genewskie, biegnie dalej w kierunku południowym, wreszcie rozległą deltą uchodzi do Zatoki Lwiej (Morze Śródziemne) na zach. od Marsylii.

${ }_{111}$ O pochodzeniu Rodanu od ojkonimu informuje już Pliniusz Starszy (Nat. hist. III, 33: „ubi Rhoda Rhodiorum fuit, unde dictum [...] Rhodanus amnis”). Por. też Hieronymus, Commentaria in epistolam ad Galatas, II, 3, 425-426, PL 26, 354: „oppidum Rhoda, coloni Rhodiorum locaverunt: unde amnis Rhodanus nomen accepit”. Nazwę miejscową Rhodus (wzgl. Rhoda) utożsamia się z Rhodanusia (gr. 'Podavovoía), kolonią założoną ok. 400 p.n.e. przez mieszkańców Massalii (dzis. Marsylia). Zob. Sid. Apoll.

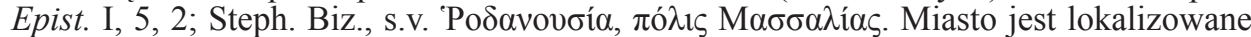
w okolicach dzisiejszej miejscowości gminnej Saint-Montan (w departamencie Ardèche). Zob. F. Haug, Rhoda, w: Paulys Realencyklopädie der classischen Altertumswissenschaft, vol. 2/1, red. W. Kroll - K. Witte, Stuttgart 1914, 759. Nie ma wątpliwości, że nazwa miejscowa została urobiona od nazwy rzecznej i nie ma nic wspólnego z miastem Rhodus, rzekomo założonym przez kolonistów pochodzących z wyspy Rodos. Według onomastów

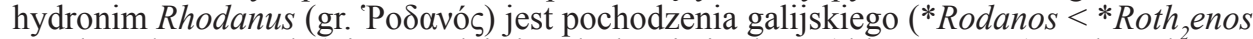
'[rzeka] płynąca stale') i wywodzi się od rdzenia ie. *ret- ('biec, toczyć'). Zob. Pokorny, Indogermanisches, s. 866; Rix, Lexikon, s. 507.

${ }_{112}$ Biskup z Sewilli w innym miejscu Etymologii (XIII, 16, 2) podaje explicite, że mianem Morza Tyrreńskiego określa się tę część Morza Śódziemnego, która rozciąga się pomiędzy Zatoką Liguryjską (sinus Ligusticus) a zachodnimi wybrzeżami Italii. Oznacza to, że Rodan - wykorzystując Izydorową nomenklaturę - wpada nie do Morza Tyrreńskiego, lecz do Zatoki Galijskiej (sinus Gallicus), przylegającej do prowincji narboneńskiej (Narbonensis provincia).

113 Por. Ambrosius, Hexaemeron, II, 3, 12, PL 14, 163: „Rhodanus rapido concitus cursu Thyrrheni aequoris freta scindens, in quo non mediocre fertur navigantium pericu- 
30. Ren (Rhenus) $)^{114}$ miał zostać tak nazwany przez związek z Rodanem, ponieważ wypływa z tej samej co on prowincji ${ }^{115}$. Ren to rzeka Germanii, którą zalicza się do trzech największych cieków Europy ${ }^{116}$. Toczy swe wody od szczytów Alp aż do głębin Oceanu (tj. Morza Północnego) ${ }^{117}$.

31. Rzeka Iberus ${ }^{118} \mathrm{w}$ dawnych czasach dała nazwę całej Hiszpanii1" ${ }^{119}$.

lum, dum inter se maris fluctus et amnis fluenta decertant" ("Rodan rozdziera szybkim biegiem fale morza Tyrreńskiego, a z powodu walki, jaką toczą ze sobą fale morskie, grozi na nim niemałe niebezpieczeństwo dla żeglarzy'). Zob. Sw. Ambroży, Hexaemeron, tł. W. Szołdrski, Warszawa 1969, 69.

114 Ren (niem. Rhein, fr. Rhin, hol. Rijn) wypływa ze źródeł wytryskających w masywie San Gotardo (Alpy Szwajcarskie), przepływa przez Jezioro Bodeńskie, tworzy naturalną granicę między Francją i Niemcami. Deltą Renu i Mozy uchodzi do Morza Północnego na zachód od Rotterdamu.

115 Objaśnienie Izydora, stawiające w związku etymologicznym nazwy Rhenus i Rhodanus, polega na podobieństwie dźwiękowym obu nazw wodnych. Współcześni językoznawcy zgodnie przypisują galijską genezę hydronimowi łac. Rhēnus (< gr. 'Pñvos). Jego postać praceltycka miała brzmieć $*$ Reinos i wywodzić się od rdzenia pie. ${ }^{*} h_{3} r e i H$ ('falować, wrzeć, kipieć, wirować, kręcić się'). Zob. przyp. 17.

116 Ren jest rzeczywiście trzecią po Wołdze i Dunaju najdłuższą rzeką Europy (1326 $\mathrm{km})$.

117 Por. Ambrosius, Hexaemeron, II, 3, 12, PL 14, 163: „Rhenus de iugo Alpium usque in Oceani profunda cursus suos dirigens, Romani memorandus adversus feras gentes murus imperii" ('Ren płynie ze szczytów Alp i kieruje swój bieg ku głębi oceanu i stanowi mur ochronny cesarstwa przeciw dzikim ludom'). Zob. Św. Ambroży, Hexaemeron, tł. W. Szołdrski, Warszawa 1969, 69.

118 Łac. Iberus a. Hiberus, obecnie Ebro, druga co do wielkości rzeka Półwyspu Iberyjskiego ze źródłami w okolicach Pico Tres Mares (na granicy dwóch prowincji: Cantabria i Burgos), przepływa m.in. przez Logroño i Saragossę, wpada deltą do Morza Śródziemnego w prowincji Tarragona. Hydronim posiada obfitą atestację antyczną, np. ”I $\beta \eta \rho$, ,I $\beta \eta \rho о \varsigma$ (np. Polib., Hist. II 35, 2; Strabon, Geogr. III 3, 8), Hiberus \|I Iberus (np. Caes. Civ. I, 60; Plin. Nat. hist. III, 21). Zob. Faure Sabater, Diccionario, s. 215. Uczeni zestawiają nazwę rzeki z baskijskim apelatywem ibai, hibai ('rzeka') i pokrewnym z nim wyrazem ibar ('dolina, żyzny teren pomiędzy górami, szeroka równina porośnięta trawą) ). Zob. J.M. Albaigès, Enciclopedia de los topónimos españoles, Barcelona 1998, 238-239; J.L. García Alonso, La Península Ibérica en la Geografía de Claudio Ptolomeo, Vitoria 2003, 173; R.L. Trask, Etymological Dictionary of Basque, Sussex 2008, 217.

119 Hiszpania w starożytności nosiła alternatywną nazwę Iberia \| Hiberia, utworzoną od hydronimu Iberus $\|$ Hiberus. Zob. m.in. Isid. Etym. XIV, 4, 28: „Hispania prius ab Ibero amne Iberia nuncupata”; Iust. Epit. XLIV, 1, 2: „Hispaniam veteres ab Hibero amne primum Hiberiam [...] cognominaverunt”; Amm. Res gest. XXIII, 6, 21: „Hiberia ex Hibero, nunc Hispania"; F. Villar, Gli indoeuropei e le origini dell'Europa, Bologna 1997, 503. 
32. Mineus ${ }^{120}$, rzeka w Galicji ${ }^{121}$, wzięła nazwę od koloru pigmentu, który występuje w niej w dużej ilości ${ }^{122}$.

33. Rzeka Durius ${ }^{123}$ została tak nazwana przez Greków, jak gdyby miała związek z greckim wyrazem ,dorycki” (Doricus) ${ }^{124}$. Rzeka Tag (Tagus) ${ }^{125}$

120 Rzeka w źródłach łacińskich funkcjonowała pod nazwą Minius (Plin. Nat. hist. IV, 112; Mela, Chor. III, 10). Obecnie nosi nazwę Miño (po hiszpańsku), Minho (po portugalsku). Rzeka (o długości $350 \mathrm{~km}$ ) wypływa z Laguna de Fuente Miña, przepływa przez miasta Lugo, Orense i Tuy, kończy bieg w Oceanie Atlantyckim, tworząc estuarium pomiędzy La Guardia i Caminha. Ciek w dolnym biegu stanowi granicę Hiszpanii i Portugalii (o długości $75 \mathrm{~km}$ ).

${ }_{121}$ Galicja (łac. Gallicia, Gallaecia \|| Callaecia), obecnie autonomiczny region Hiszpanii (w pn.-zach. części Półwyspu Iberyjskiego) z głównym miastem Santiago de Compostela.

${ }_{122}$ Hydronim Minius z łac. apelatywem minium n. ('cynober, czerwony pigment, jasna czerwień, minia, czerwień ołowiu') zestawił już historyk rzymski Pompejusz Trogus (I p.n.e./I n.e.). Zob. Iust. Epit. XLIV, 3, 4: „Regio Gallicia [...] uberrima [...] minio, quod etiam vicino flumini nomen dedit". Izydor w innym miejscu swoich Etymologii powtarza tę samą informację (XIX, 17, 7): „Minium primi Graeci in Ephesiorum solo invenisse traduntur. Cuius pigmenti Hispania ceteris regionibus plus abundat; unde etiam nomen proprio flumini dedit”. Zob. Albaigès, Enciclopedia, s. 390. W większości współczesnych opracowań nazwę rzeki uznaje się za przedromańską i zalicza do szeregu europejskich hydronimów, zawierających substratowy (przedindoeuropejski) rdzeń $m-n$, którego semantyka nie została jak dotąd sprecyzowana. Por. Main (Niemcy), Maine (Francja), Mień, Mianka, Mienia, Minina (Polska) etc. Zob. Staszewski, Mały słownik, s. 280; Faure Sabater, Diccionario, s. 37, 403. Za indoeuropejskim pochodzeniem rzeki optują liczni onomaści, którzą wywodzą hydronim od ie. rdzenia *mei- ('zmieniać, zamieniać'). Zob. Pokorny, Indogermanisches, s. 710; Rix, Lexikon, s. 426; J. Udolph, Die Stellung der Gewässernamen Polens innerhalb der alteuropäischen Hydronymie, Heidelberg 1990, 159-164; Z. Babik, Najstarsza warstwa nazewnicza na ziemiach polskich $w$ granicach wczesnośredniowiecznej Stowiańszczyzny, Kraków 2001, 173-174; E. Bascuas López, La hidronimia de Galicia: Tres estratos. Paleoeuropeo, celta y latino, „Estudios Mindonienses" 24 (2008) 534.

123 Obecnie Duero (hiszp.), Duoro (port.). Trzecia pod względem długości rzeka (897 km) na Półwyspie Iberyjskim, wypływająca w Hiszpanii w okolicach la Peña de Urbión na granicy prowincji Rioja i Soria, uchodzi do Oceanu Atlantyckiego w portugalskim mieście Oporto. Hydronim jest dobrze udokumentowany w źródłach greckich ( $\Delta$ oúpısos, $\Delta$ ópıs) i łacińskich (Durius). Nazwę rzeki wywodzi się od celtyckiego rdzenia hydrograficznego *dur- ('woda, rzeka, nurt wody'), poświadczonego w nazwach wielu europejskich rzek, np. hiszp. Duruelo (demin. < n. w. Duero), Dore (dwie rzeki w Piemoncie = łac. Duria), Thur (rzeka w pn.-wsch. Szwajcarii). Zob. Albaigès, Enciclopedia, s. 236. Morfem leksykalny *dur $\|$ *tur jest niekiedy zestawiany z baskijskim wyrazem iturri ('źródło'). Zob. Staszewski, Mały słownik, s. 122; Faure Sabater, Diccionario, s. 210-211. Portugalczycy wierzą, że nazwa rzeki Duoro powstała ze skrócenia uprzedniej postaci río de Ouro (= hiszp. río de oro, dosł. 'złota rzeka'). Zob. Faure Sabater, Diccionario, s. 211.

$124 \mathrm{Na}$ skojarzenie hydronimu Durius z odetnicznym przymiotnikiem ,dorycki” (Doricus) wpłynęło zapewne brzmieniowe podobieństwo łac. formy Dorius $(<$ gr. $\Delta \omega ́ \rho 1 o \varsigma$ 'ts.').

125 Tag (hiszp. Tajo, port. Tejo) jest najdłuższą rzeką Półwyspu Iberyjskiego (1007 $\mathrm{km})$. Bierze początek w prowincji Teruel w pobliżu miasta Alcantara, przepływa przez 
zawdzięcza swą nazwę hiszpańskiej Kartaginie $(\operatorname{Cartago})^{126}$, w okolicach której bierze początek ${ }^{127}$; obfituje w złotonośne piaski ${ }^{128}$ i z tego powodu jest przedkładana nad pozostałe rzeki [obu] Hiszpanii ${ }^{129}$.

34. Rzeka Betis (Baetus) $)^{130}$ dała nazwę prowincji Baetica ${ }^{131}$. O cieku mówi Marcjalis: „Baetis olivifera crinem redimite corona, / aurea qui ni-

prowincje Guadalajara, Cuenca, Toledo, Madrid y Cáceres, kończy bieg w Oceanie Atlantyckim w pobliżu Lizbony, tworząc wielkie rozlewisko zw. estuarium.

126 Chodzi o Nową Kartaginę (łac. Carthago Nova, dzis. hiszp. Cartagena w Murcji), kolonię kartagińską (zw. po fenicku Qart Hadasht, dosł. 'nowe miasto'), założoną w 228 p.n.e. przez Hazdrubala. Powiązanie nazwy rzecznej Tagus z ojkonimem Cartago (zam. Carthago) jest klasycznym przykładem tzw. etymologii ludowej (naiwnej). W starożyt-

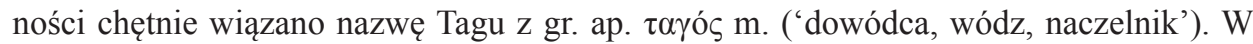
czasach nowożytnych próbowano wywodzić hydronim od fen. dag ('ryba'; por. hebr. $d \bar{a} g$ m. - 'ryba', ugaryckie $d g$ coll. - 'ryby') lub od fenickiego teonimu Dagon. Zob. Faure Sabater, Diccionario, s. 554-555. Kastylijska etymologia ludowa wiąże nazwę Tagu (hiszp. Tajo) z urwiskami (hiszp. tajo), z powodu których rzeka często zwęża swój nurt. Zob. Albaigès, Enciclopedia, s. 580. Współcześnie łączy się nazwę rzeki z przedromańskim (tj. nieindopeuropejskim) rdzeniem oronimicznym *tag- o niesprecyzowanym znaczeniu, poświadczonym w takich nazwach, jak Taga (Lérida), Tagamanent, Tagast (Barcelona), Tagomago (Ibiza) etc. Zob. Faure Sabater, Diccionario, s. 554-555. Za (wodną) indoeuropejską genezą Tagu opowiadał się J. Leite de Vasconcellos, który wywodził hydronim z celt. *stago-s < ie. *stag- ('kapać'; > gr. $\sigma \tau \alpha \dot{\zeta} \omega$ 'ts.'). Por. bret. Ster ('rzeka, potok'; <*stag-rā). Zob. García Alonso, La Península Ibérica, s. 90.

127 Źródła Tagu, wytryskające na zboczach góry Sierra de Albarracín (na wysokości 1593 m) w paśmie Montes Universales (Góry Iberyjskie), znajdują się w rzeczywistości w dużej odległości od Cartageny (ponad $300 \mathrm{~km}$ w linii prostej).

128 O złotonośnych (złotodajnych) piaskach Tagu pisał już Pliniusz Starszy (Nat. hist. IV, 115: „Tagus auriferis harenis celebratur”). Autorzy łacińscy najczęściej określają Tag poetyckim epitetem aurifer ('złotonośny'): Catul., Carm. 29, 19: „amnis aurifer Tagus”; Mart. Ep. X, 96, 3: ,auriferumque Tagum”.

129 Izydor ma zapewne na myśli dwie części antycznej Hiszpanii: Hiszpanię Bliższą (Hispania citerior), zwaną od czasów Augusta H. Tarraconensis, z głównym ośrodkiem w Carthago Nova, i Hiszpanię Dalszą (Hispania ulterior) z miastem Corduba. Zob. Isidorus, Etymologiae XIV 4, 30: „Duae sunt autem Hispaniae: Citerior, quae in septentrionis plagam a Pyrenaeo usque ad Carthaginem porrigitur; Ulterior, quae in meridiem Celtiberis usque ad Gaditanum fretum extenditur".

130 Obecnie Guadalquivir (< arab. wād̄̄ al-kabīr, dosł. 'rzeka wielka'). Zob. Faure Sabater, Diccionario, s. 274; Albaigès, Enciclopedia, s. 294. Piąta co do wielkości rzeka Półwyspu Iberyjskiego (657 km) wypływa z gór Sierra de Cazorla (Jaén), przepływa przez słynne miasta Sewillę i Kordobę, uchodzi do Zatoki Kadyksu (Ocean Atlantycki) przy miejscowości Sanlúcar de Barrameda.

131 Rzymska prowincja Hispania Baetica, stanowiąca część H. ulterior, w dużej mierze pokrywała się z terytorium dzisiejszej Andaluzji. 
tidis vellera tingis aquis" ('Betisie, mający włosy uwieńczone wieńcem oliwnym, / który przejrzystymi wody ozłacasz runo') ${ }^{132}$. Rzeczywiście, wełna owcza zanurzona w jej wodach przybiera ładną barwę. Rzeka otrzymała nazwę Betis, ponieważ spływa obniżonym terenem: Grecy bowiem na określenie czegoś położonego w dole lub zagłębionego używają wyrazu $\uparrow$ bitin $\uparrow^{133}$.

35. Podczas powodzi niektóre rzeki są blokowane przez zwaliska osuniętej ziemi. W tym czasie mogą też tworzyć się nowe rzeki, które podziemnymi szczelinami wypływają obficie na powierzchnię ${ }^{134}$.

Z języka łacińskiego przełożyła oraz wstępem i komentarzem opatrzyła Elwira Kaczyńska ${ }^{135}$

132 Martialis, Epigrammata XII 98, 1-2.

133 Zarejestrowany w kodeksach zapis $\uparrow$ bitin $\dagger$ (zapewne acc. sg. neutrius generis) jest

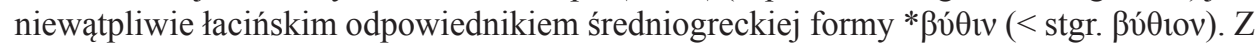
łacińskich objaśnień tego wyrazu (,bitin enim Graeci humile vel mersum vocant”) niedwuznacznie wynika, że hydronim ten łączono w starożytności z greckim apelatywem

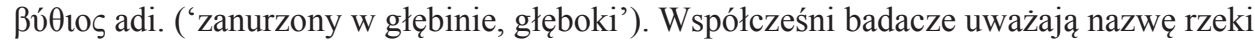
Baetis za przedromańską, wywodząc ją od hipotetycznej bazy iberyjskiej (a więc przedindoeuropejskiej) *bai-, spokrewnionej z baskijskim apelatywem ibai ('rzeka'). Zob. Faure Sabater, Diccionario, s. 97; García Alonso, La Península Ibérica, s. 33.

134 Fragment ten jest zapowiedzią następnego rozdziału poświęconego powodziom (Etym. XIII, 22: De diluviis).

135 Dr hab. Elwira Kaczyńska, profesor nadzwyczajny w Katedrze Filologii Klasycznej Uniwersytetu Łódzkiego, e-mail: elwira.kaczynska@uni.lodz.pl; aradaina@ gmail.com, ORCID: 0000-0002-4545-1927. 